Article

\title{
Flood Hazard and Risk Zonation in North Bihar Using Satellite-Derived Historical Flood Events and Socio-Economic Data
}

\author{
Gaurav Tripathi (D, Arvind Chandra Pandey and Bikash Ranjan Parida *(D)
}

check for

updates

Citation: Tripathi, G.; Pandey, A.C.; Parida, B.R. Flood Hazard and Risk Zonation in North Bihar Using Satellite-Derived Historical Flood Events and Socio-Economic Data. Sustainability 2022, 14, 1472.

https://doi.org/10.3390/ su14031472

Academic Editors: Basu Bidroha, Laurence Gill, Francesco Pilla and Srikanta Sannigrahi

Received: 23 December 2021

Accepted: 25 January 2022

Published: 27 January 2022

Publisher's Note: MDPI stays neutral with regard to jurisdictional claims in published maps and institutional affiliations.

Copyright: (c) 2022 by the authors. Licensee MDPI, Basel, Switzerland. This article is an open access article distributed under the terms and conditions of the Creative Commons Attribution (CC BY) license (https:// creativecommons.org/licenses/by/ $4.0 /)$.
Department of Geoinformatics, School of Natural Resource and Management, Central University of Jharkhand, Ranchi 835222, India; gaurav.tripathi@cuj.ac.in (G.T.); arvind.pandey@cuj.ac.in (A.C.P.)

* Correspondence: bikash.parida@cuj.ac.in

\begin{abstract}
North Bihar is one of the most flood-affected regions of India. Frequent flooding caused significant loss of life and severe economic damages. In this study, hydroclimatic conditions and historical flood events during the period of 2001 to 2020 were coupled over different basins in North Bihar. The main objective of this study is to assess the severity of floods by estimating flood hazards, vulnerability and risk in North Bihar. The uniqueness of this study is to assess flood risk at the village level as no such study was performed earlier. Other thematic data, namely, land-use and drainage networks, were also utilised with flood maps to validate the severity of the event. MOD09A1 satellite data (during 2001-2020) derived indices were used to derive inundation extents and flood frequency. Socio-economic vulnerability (SEV) was derived based on seven census parameters (i.e., population density, house-hold density, literacy rate, agricultural labour, and cultivator, total male, and female) and coupled with flood hazard to derive flood risk over the study region. The study exhibited that a total $\sim 34 \%$ of the geographical area of North Bihar was inundated in the last 20 years and the maximum flood extent was seen in 2020 . Flood risk map exhibited that $\sim 7 \%, \sim 8 \%, \sim 13 \%, \sim 4 \%$, and $\sim 2 \%$ of the geographical area was mapped under Very High, High, Moderate, Low, and Very Low categories, respectively. The 2770 and 3535 number of villages was categorized under Very High and High flood risk zone which are located in north-central and central-western regions. These findings can be applied to distinguish and classify areas of various risk zones to assist in flood mitigation and management activities.
\end{abstract}

Keywords: North Bihar; flood frequency; flood characterization; hazard; vulnerability; risk

\section{Introduction}

During the last few decades, hydro-meteorological hazards, namely floods, droughts, and extreme weather events are causing catastrophes around the world [1,2]. Hydrological extreme events and their occurrences and magnitude are increasing due to global climate change $[3,4]$. Its multitude of impacts are seen across the various sector and its subsectors such as agriculture (crops, livestock, fisheries and forestry), environment, ecosystems, health, economy and increasing vulnerability of these hazards can be attributed to rapid growth in population, unplanned urbanization, and other anthropogenic activities [3] which affected almost 1 billion people worldwide [5]. Floods are generally originated from fluvial, pluvial, coastal and storms sources and cause significant economic, environmental, and social effects. Flooding is the major threat posed by climate change, especially in Southeast Asia with 237 million people at risk by 2050s from China, India, Vietnam, Bangladesh, Indonesia and Thailand [6]. Flood risk and associated human morality and infrastructure losses are also heavily concentrated in these countries because of the high vulnerability and coping capabilities of people [7]. In Indonesia, the Philippines and Singapore, rainfall-related impacts of climate change, such as floods or rainfall-induced landslides, are becoming concerned [8]. Moreover, river floods are projected to appear 
frequently and intense in some regions of Southeast Asia [8]. The extremity of extreme rainfall-induced flooding in Chennai (India) in 2015 was attributed to the warming trend of sea surface temperatures (SST) in the Bay of Bengal (BoB) and the strong El-Nino conditions [8,9]. An extreme weather event in Chennai in 2021 had recorded $210 \mathrm{~mm}$ of rainfall on a single day (6th November) due to the northeast monsoon which has been impacted by La Nina, a complex weather pattern caused by variations in ocean SST in the equatorial band of the Pacific Ocean [10]. Hence, to reduce flood losses, one has to understand both current and future risks, develop effective strategies, and increase the resilience of communities to flooding. This needs innovative approaches and space-based tools to assess flood zones, risk and resilience.

Geospatial techniques have emerged as an essential tool for mapping and monitoring flood hazards [11]. Some of the open-source platforms are available viz. Alaska Satellite Facility (ASF), United States Geological Survey (USGS)-Earth Explorer, etc. which ensures the availability of near real-time optical remote sensing satellite data with high spatial and temporal resolutions worldwide. The space-borne data such as Moderate Resolution Imaging Spectroradiometer (MODIS), Landsat, Indian Remote Sensing (IRS), and Sentinel have been used for determining the flood extent [12]. The only limitation with optical satellite data is cloud cover, it cannot sense beyond this. Getting clear satellite images during the rainy season is merely possible from optical sensors, whereas the composites products are sometimes beneficial for flood monitoring at regional scales. For instance, the MODIS-based near real-time (NRT) product was widely used for inundation mapping and impact analysis over several river basins worldwide $[2,13,14]$. Additionally, satellite images captured by the optical sensors have been broadly used for waterlogged extent mapping, standing water depth mapping, flood hazards, vulnerability and risk assessment $[15,16]$.

Satellite reflectance data have been also employed for deriving spectral indices, such as the Normalized Difference Water Index (NDWI) and modified NDWI (mNDWI) to assess flooded regions as well as soil moisture zoning [17-20]. Other multi-spectral based indices such as the Normalized Difference Vegetation Index (NDVI), Enhanced Vegetation Index (EVI), Water Ratio Index (WRI), Spectrum Photometric Water Index (SPWI), and Standardized Photometric Water Index (SPWI) are utilized for the delineation of flooded areas and characterizing floods (e.g., estimating turbidity, sediments, etc.) [21-23]. Most of these spectral indices (SIs) have utilized near-infrared (NIR) band as floodwater reflects the lowest amount of light energy which helps to identify flooded pixels [24]. The NDWI and $\mathrm{mNDWI}$ are based on green and near-infrared bands, which can easily discriminate between water and non-water pixels $[17,25]$. Other than optical sensors, microwave sensors (Synthetic Aperture Radar (SAR)) are also used for flood inundation mapping and floodwater depth mapping as they can distinguish land and water precisely $[16,26]$. In addition to satellite data, several studies have proposed that various empirical, hydrodynamic, and 1D, 2D, and 3D flood models could be used for flood inundation and depth mapping [16,27]. Data-driven models e.g., Machine Learning (ML) methods are becoming popular because they can numerically do flood forecasting purely based on historical flood data without requiring knowledge of any physical processes [28]. In comparison with statistical models, ML methods showed greater accuracy while dealing with complex hydrological systems such as floods $[29,30]$. Several other ML algorithms, e.g., neuro-fuzzy (NF), convolutional neural network (CNN), support vector machine (SVM), and support vector regression (SVR), were also proved very effective for current as well as historical flood mapping, forecasting, and prognosis [31-33]. Accurate flood inundation extent mapping is a crucial input for hydrological models for damage assessment, vulnerability and flood risk evaluation. It also assists rescuers during flood disasters.

In order to identify vulnerability in a multidimensional space, numerous dimensions of vulnerability elements and datasets are used. Typically, multi-criteria decision analysis (MCDA), cluster analysis, and Analytical Hierarchy Process (AHP) techniques are employed for vulnerability and flood risk analysis [34-36]. High-resolution datasets (NOAA-AVHRR) coupling with Geographical Information Sciences (GIS) were used to 
prepare flood hazard maps for Bangladesh [37]. Based on several studies, it has been recognized that socio-economic/physical/environmental vulnerability data along with flood hazard index are crucial components in flood risk assessment $[25,35,38]$. Some of the vital elements for flood hazard zonation are land cover, slope, elevation profile, evacuation route, proximity to breach sites (e.g., school, hospital, road, etc.), proximity to confluence, proximity to rivers, soil moisture. Additionally, to examine socio-economic vulnerability, population data, shelter home, statistical data on education (i.e., literacy rate, dependency on education and related jobs etc.), age proportion, labour (agricultural and migrated), cultivator, family structure, and social dependence are mainly considered [39,40]. However, recognition of the socio-economic data from different sources in the local context is more useful in mapping and analyzing the spatiotemporal dynamics of flood risk [41,42]. MCDA methods are frequently employed to examine integrated datasets comprising multiple geomorphological, hydrological, and socio-economic factors for vulnerability and flood risk analysis [35]. Several studies have considered MCDA for the regionalization of flood risk areas $[35,43]$. Clustering techniques are employed to identify flood risk zones in central India accompanying biophysical and socioeconomic variables, such as K-means for regional flood frequency analysis [44]. Satellite datasets comprising multi-sensor optical (IRS) and SAR (RADARSAT) data are employed to identify villages falling under various flood hazard zones in the Kopili river basin of Brahmputra river in Assam [7]. To investigate flood risk at the regional level in the upper Brahmputra River valley, a methodology was adopted based on GIS-based MCDA by integrating stakeholders' knowledge, hazard indicators (e.g., elevation, slope, and proximity to breach sites, drainage confluences, rivers), and vulnerability indicators (e.g., agriculture, safe drinking water, evacuation route, and elevated household/flood shelter) [42]. Studies have evaluated the flood hazard and flood vulnerability as separate entities and combines them to assess flood risk in the North Bihar region by considering various geomorphological, hydrological, socio-physical/environmental and socio-economical/physical parameters at block, municipality, and district level $[15,35,38]$. Even though studies have advised regionalizing flood zones based on hydrographic boundaries, this is rarely practicable in countries such as South Asia due to a lack of datasets at administrative levels and restrictions on data sharing mechanisms in transboundary basins. Furthermore, using administrative units as the foundation for regionalizing flood-risk areas allows authorities to allocate resources such as insurance premium subsidies [45,46]. The implication of hydraulic models in flood risk assessment is becoming more frequent and worthful. Some of the studies applied a variety of hydrological as well as hydraulic models to assess flood hazards for different applications [15,36]. The 1-D hydraulic model along with Digital Elevation Model (DEM) has been used to assess flood hazard, vulnerability and risk [47]. A new dimension in flood vulnerability assessment is introduced, which has focused on community-level flood vulnerability assessment by analyzing satellite images, coupled with a structured questionnaire, criteria mapping, observation and the secondary data [48].

Studies on flood risk assessment are limited in the North Bihar region in India which is a major flood-prone area of India. Various researchers have addressed the flooding problem and prognosis in the region utilizing multi-temporal satellite datasets and geospatial tools from time to time [2,49-51]. However, there is a lack of information on long-term flooding patterns to identify flood risk zones and reduction mechanisms. The present study demonstrates the utility of satellite-based flood inundation mapping for flood hazard, vulnerability and risk assessment. Therefore, the specific aim of this case study was to (1) assess long-term flood hazards spanning from 2001 to 2020, (2) establish linkage of flood hazards with sinuosity, drainage density, Euclidean distance from road and river, and relief map, (3) assess impacts of floods on agriculture and built-up, and (4) map flood vulnerability and flood risk in the region based on several socio-economic parameters. 


\section{Study Area}

North Bihar is located between latitude $25^{\circ} 20^{\prime} 01^{\prime \prime} \mathrm{N}$ to $27^{\circ} 31^{\prime} 15^{\prime \prime} \mathrm{N}$ and longitude $83^{\circ} 19^{\prime} 50^{\prime \prime}$ E to $88^{\circ} 17^{\prime} 04^{\prime \prime}$ E with a geographical area of $54,223.02 \mathrm{~km}^{2}$ (Figure 1). It comprises $57.6 \%$ of the total geographical area and consists of 21 districts out of 38 districts of the Bihar state. Bihar is surrounded by the humid West Bengal in the east and the sub humid Uttar Pradesh in the west, surrounded by Nepal in the north and Jharkhand in the south. Ganges and Kosi are the main rivers, supplying most of the water to this state which further divided Bihar into two parts (i.e., North Bihar and South Bihar) by the river Ganges that passes through the middle from west to east. The geographical setting of the river channels of northern Bihar plains is the most dynamic system globally [52,53]. There are more than 250 seasonal and permanent rivers/dhars are present in the region which contributes majorly to flooding. A significant part of the land is flat with some mountains in the southern part. Bihar has a tropical monsoon climate with the average maximum and minimum temperature ranges between $24-25^{\circ} \mathrm{C}$ and $8-10{ }^{\circ} \mathrm{C}$, respectively. The hottest months are from April to June, whilst the coldest is during December to January. Most of the rainfall $(80-90 \%)$ is concentrated during the monsoon season (mid-June to midOctober) and these months are very important for agriculture in this region. The 21 years of climatological mean rainfall map based on PERSIANN Dynamic Infrared-Rain Rate (PDIR-Now) during July to September showed that rainfall varied from 200 to $375 \mathrm{~mm}$ and was distributed across all basins, albeit the Tibetian plateau showed relatively lower rainfall (Figure $1 b)$.

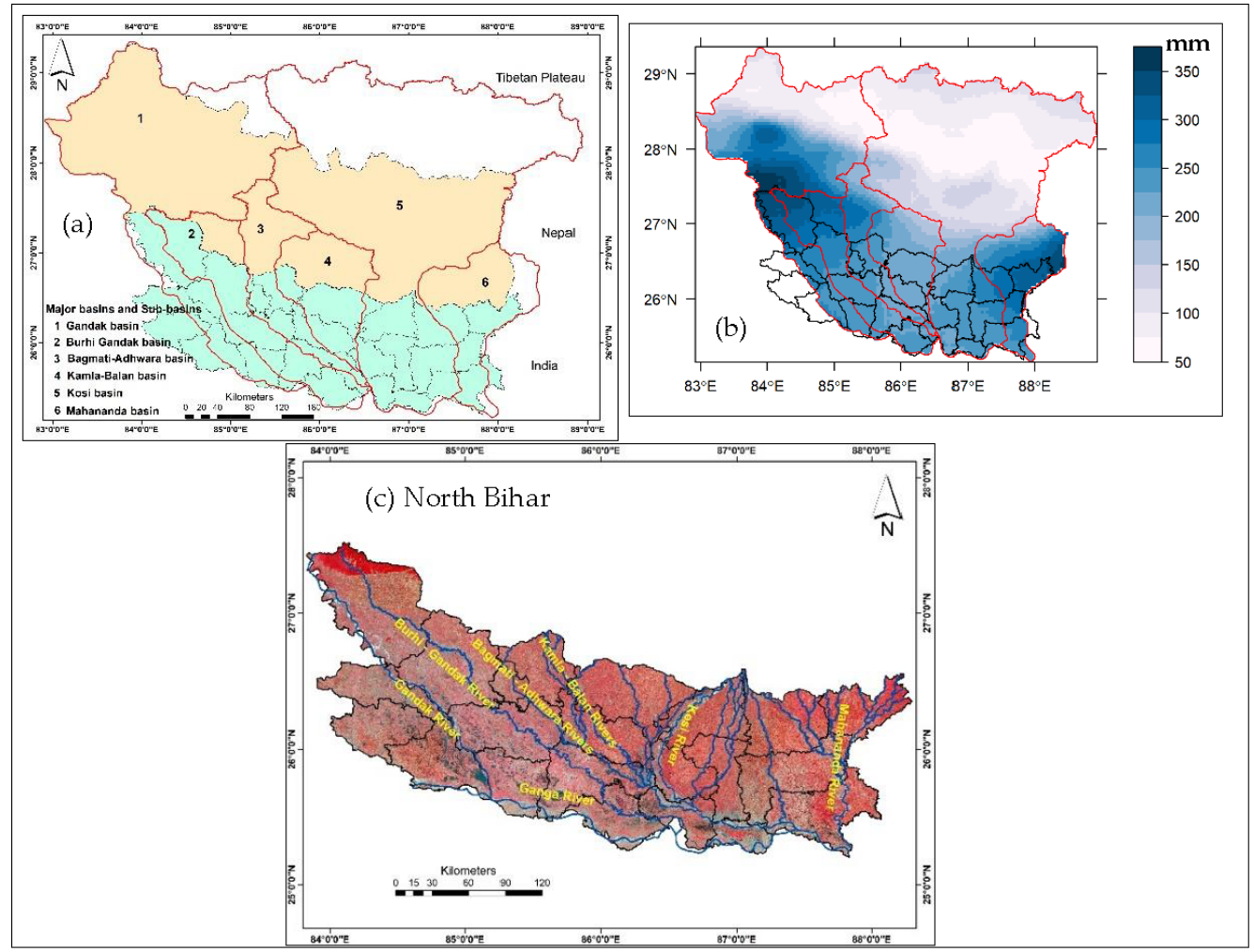

Figure 1. Study region with major river basins and sub-basins in North Bihar (a), 21 years of the climatological mean (2000-2020) rainfall in mm based on PDIR-Now (b). The False Color Composite (FCC) image in (c) is derived from Sentinel-2 images (i.e., median image over March to June 2020 to remove cloud pixels).

Based on the genesis, floods in India are due to riverine, glacial outburst, dam break, and storm surge [50,51]. North Bihar recurrent floods are mostly due to extreme rainfallinduced riverine floods, and some of the major flood events in the study region are 1987, 
$1998,2000,2001,2003,2004,2008,2010,2013,2017,2018$ and 2020. It was reported that $\sim 16.5 \%$ geographical land of Bihar was prone to flooding with nearly $76 \%$ of the population living under the threat of flood in the study region [16]. Typically, floods are a recurring event observed annually that destroys thousands of human lives including live stocks and other assets [54]. In comparison to South Bihar, North Bihar is more vulnerable to flood due to its geographical-setting which receives a huge amount of water from the upstream river catchments flows through Nepal and Tibetan Plateau [2]. Due to the succession of high flows and unexpected changes in slope from steep rocky terrain to nearly flat terrain, this area comes under a high flood risk zone [16,54]. During the last 30 years, northern Bihar plains have experienced the highest and disastrous flood occurrences which also results in waterlogging at a major scale in low-lying areas throughout the year [35]. Kosi, Gandak, and Burhi Gandak are the major tributaries present in the region along with some of the minor viz. Kamla Balan, Adhwara group of rivers, etc., carries a huge amount of water and results in a massive inundation for the low lying area which also creates the biggest threat to loss of life, livelihood, and infrastructure [52].

Although there are industries present in the region, agriculture is the pivot of economic growth, majorly affected due to repetitive flooding events, needs to be prevented so that the crop yield can be increased regularly and living can be good [2]. Therefore, there is a need for better planning of land resource utilization that can reduce flood effects over hazardprone areas. Recently, Bihar has made a tremendous and positive change in the monitoring and assessment of the flood hazards with the help of the Flood Management Information System Centre (FMISC) and State Disaster Management Authority, Patna (BSDMA). The open-source remote sensing satellite images in near real-time are also serving as vital information for emergency response support. Conventional methods like field survey and aerial observations for flood extent mapping require extensive work, large manpower, more time, and combinedly make it costly in comparison to Remote Sensing and GIS approaches. The capability of remote sensing made it more reliable and applicable in monitoring and assessing the impact of floods over land and urban areas during and immediately after the occurrence of flood events [16].

The Advanced Land Observing Satellite (ALOS) Phased Array type L-band Synthetic Aperture Radar (PALSAR) derived Global DEM V2 (GDEM V2) and Google Earth Pro derived elevation points are used to map the topographic undulations in the study region (Figure 2). The terrain is gentle slopy to nearly flat throughout the study region, exhibits majorly very low relief. Therefore, a contour map was generated by applying the interpolation technique at an interval of 5 and $10 \mathrm{~m}$, and a relief map was also prepared based on derived contours. The relief map exhibits relief ranges from $20 \mathrm{~m}$ to more than $100 \mathrm{~m}$ over the study region. The terrain relief is also appeared as one of the major contributing factors to influence flooding patterns. Low relief region has always the potential of submergence due to high soil moisture. Such regions also have elevated groundwater levels and surface flows are higher as well.

The central and eastern part of the study region has relief between 20 to $50 \mathrm{~m}$. whereas, the western, some of the central, and northern regions were having relief variation between 60 to $90 \mathrm{~m}$. The Paschhim Champaran is the highest elevated district with the relief variation of $\sim 70 \mathrm{~m}$ to more than $100 \mathrm{~m}$. Several studies stated that waterlogging is quite prominent in lower relief zones and decrease with the increase of relief zone. 


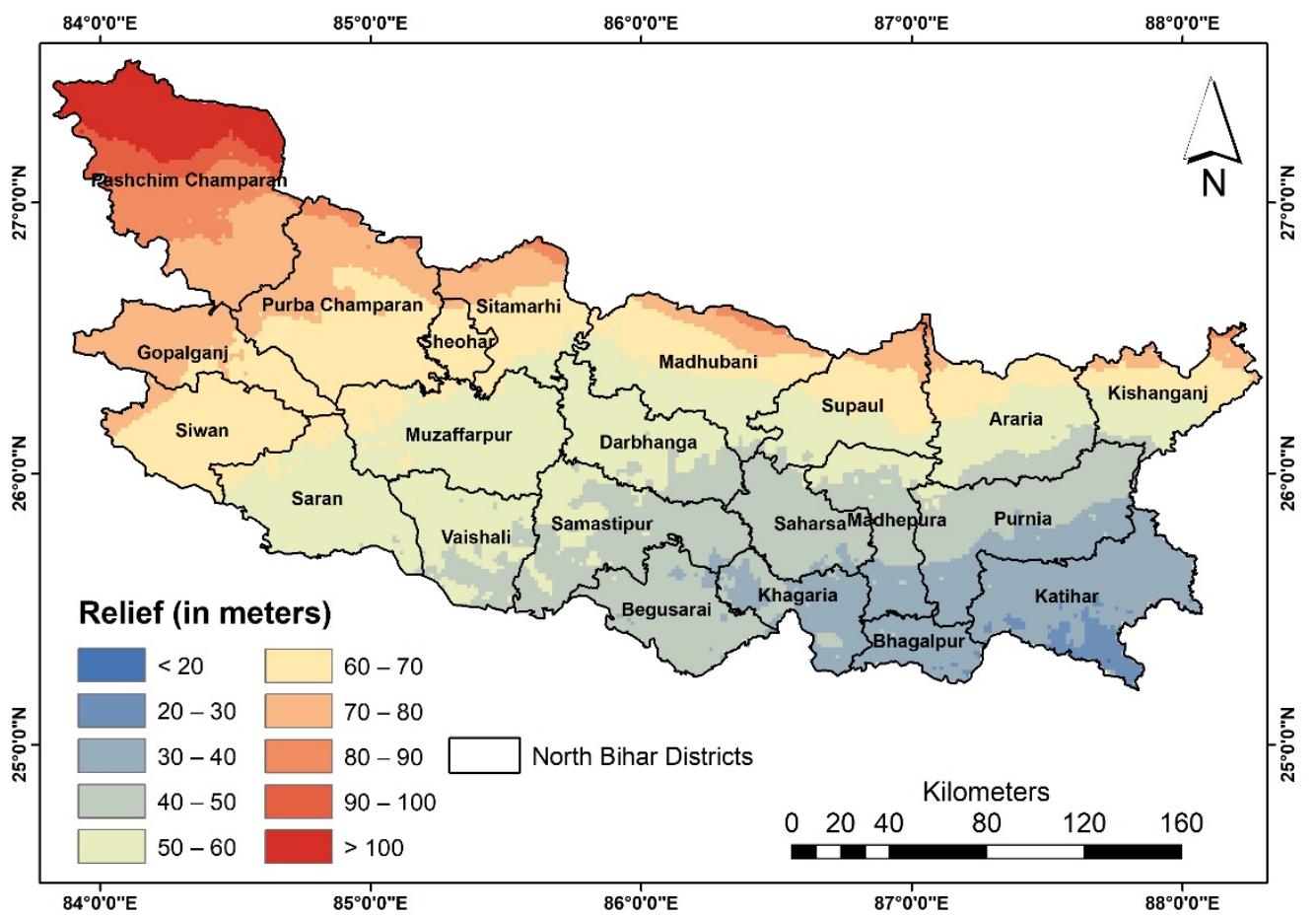

Figure 2. Relief variation in study region as derived from ALOS-based DEM. ESRI Shapefile of North Bihar districts is also overlaid.

\section{Materials and Methods}

The dataset used in this study were MODIS surface reflectance product (MOD09A1), Sentinel-2A/B optical satellite data, rainfall (PDIR-Now), Copernicus land use/land cover (LULC), ALOS based DEM, and socio-economic datasets (Census data). The detailed information is presented in Table 1. To link rainfall with flood inundation patterns, we used three-month mean satellite-derived rainfall data of PDIR-Now (CHRS Data Portal). MODIS surface reflectance products were used to map flood hazard zones. Census data such as population density, total male, female and population of cultivators, agricultural labourers, house-hold density, and literates were utilized to get village level socio-economic vulnerability. Furthermore, this information was coupled with flood hazards to generate a final risk map. Copernicus-based LULC data is used to assess the impact of flooding over various LULC.

\subsection{Data Descriptions}

\subsubsection{MOD09A1 Based Reflectance Product}

The MOD09A1 (V6) product provides surface reflectance at $500 \mathrm{~m}$ resolution and 8-day composite. These reflectance data were corrected for atmospheric conditions such as gasses, aerosols, and Rayleigh scattering. In this study, MODIS reflectance products were considered for July to September for each year during 2001-2020 to compute NDWI, $\mathrm{mNDWI}, \mathrm{SPWI}$, and EVI (Table 2). All these indices were utilized for extracting flood pixels. However, at some places where biases on flood pixels occurred, we rectified using FMISC, Patna based published annual flood reports and maps. 
Table 1. Dataset used in this study and their characteristics.

\begin{tabular}{|c|c|c|c|c|c|}
\hline Name of Dataset & $\begin{array}{c}\text { Temporal } \\
\text { Resolution }\end{array}$ & Spatial Resolution & Acquisition Date & Purpose & Source \\
\hline MOD09A1 & 8 days & $500 \times 500 \mathrm{~m}$ & $\begin{array}{l}\text { July-October } \\
(2000-2020)\end{array}$ & Flood delineation & LP DAAC \\
\hline Sentinel-2A/B & 12 days & $10 \times 10 \mathrm{~m}$ & March-June (2020) & $\begin{array}{c}\mathrm{PWB} \text { and } \\
\text { major/minor River } \\
\text { channel, } \\
\text { lineaments, and road }\end{array}$ & ASF \\
\hline PDIR-Now & 3-hourly & $4 \times 4 \mathrm{~km}$ & July-Sept (2000-2020) & $\begin{array}{l}\text { Rainfall and anomaly } \\
\text { maps }\end{array}$ & CHRS Data Portal \\
\hline Copernicus LULC & Composite & $100 \times 100 \mathrm{~m}$ & - & LULC map & Copernicus \\
\hline ALOS PALSAR DEM & Composite & $12.5 \times 12.5 \mathrm{~m}$ & - & Relief map & ASF \\
\hline Census data & 10 years & - & - & $\begin{array}{l}\text { Socio-economic } \\
\text { vulnerability } \\
\text { mapping }\end{array}$ & Census of India \\
\hline FMISC Flood Reports & - & - & $\begin{array}{l}\text { July-October } \\
(2000-2020)\end{array}$ & $\begin{array}{c}\text { To validate flooding } \\
\text { for the respective } \\
\text { years }\end{array}$ & FMISC, Patna \\
\hline
\end{tabular}

Table 2. The indices utilized to derived flood pixels based on MODIS reflectance bands.

\begin{tabular}{|c|c|c|c|}
\hline Sl. No. & Equations & & Reference/Source \\
\hline 1. & NDWI $=($ Green - NIR $) /($ Green + NIR $)$ & (1) & [17] \\
\hline 2. & $\mathrm{mNDWI}=($ Green - SWIR $) /($ Green + SWIR $)$ & $(2)$ & [55] \\
\hline 3. & $\begin{array}{l}\text { SPWI }=(\mathrm{B} 1+\mathrm{B} 4)-(\mathrm{B} 2-\mathrm{B} 6) \\
\text { Where, B1, B2, B4, B6 are the reflectance of band Red, NIR, } \\
\text { Green, and MIR respectively }\end{array}$ & (3) & [22] \\
\hline 4. & $\mathrm{EVI}=2.5^{*}\left((\mathrm{NIR}-\mathrm{R}) /\left(\mathrm{NIR}+\left(6^{*} \mathrm{RED}\right)-\left(7.5^{*} \mathrm{BLUE}\right)+1\right)\right)$ & (4) & [56] \\
\hline
\end{tabular}

\subsubsection{Sentinel-2 Optical Satellite Data}

Sentinel-2 optical satellite data is the most widely accessible satellite mission which provides moderate-to-high spatial resolution multispectral satellite measurements. It is a land monitoring mission with the constellation of two satellites that provide global coverage at every five days interval. L1C data have been available since June 2015 and L2A data have been available globally since January 2017. In this study, the satellite images during March-June, 2020 were being used to extract permanent/seasonal river streams, lineaments, major/minor roads in the North Bihar region. River centerlines were also drawn using Sentinel-2 satellite image which was further used to calculate sinuosity for each river.

\subsubsection{PDIR-Now Based Precipitation}

Precipitation Estimation from Remotely Sensed Information using Artificial Neural Networks-Cloud Classification System-Climate Data Record (PERSIANN) provides nearly global high spatio-temporal precipitation datasets. PDIR-Now provides precipitation estimates at $0.04^{\circ}$ spatial and 3-hourly temporal resolutions from March 2000 to the present over the global domain of $60^{\circ} \mathrm{S}$ to $60^{\circ} \mathrm{N}$. Development of PDIR-Now was motivated by the needs of the scientific community interested in a long-term, very high spatiotemporal resolution $\left(0.04^{\circ} \times 0.04^{\circ}\right.$ spatial and 3-hourly temporal) precipitation data record relevant for hydro climatological applications, such as the study of diurnal precipitation patterns and extreme events with heavy rain rates. The mean rainfall dataset of July-September months from 2000 to 2020 is used in this study to show and analyze rainfall anomalies for the major flooding events over the study region during the last two decades.

\subsubsection{Copernicus Land Use Land Cover}

Copernicus Land Use Land Cover data is prepared on an annual basis at a very high spatio-temporal scale with an overall accuracy of $80 \%$ (in 2019) which were also validated 
based on 28k ground-truthing points. The statistical validation meets the CEOS land product validation stage 4 requirements. Flood impacts at various LULC in the study region were assessed using Copernicus Land use data.

\subsubsection{ALOS PALSAR Based DEM}

The ALOS (PALSAR) based DEM data are available at $12.5 \mathrm{~m}$ spatial resolution and are obtained from the Japan Aerospace Agency (JAXA) portal. The DEM has been used to draw major/minor drainage. We used ALOS-based DEM because it possesses comparatively a more detailed spatial resolution than the ASTER-GDEM V2 $(30 \mathrm{~m})$ and Shuttle Radar Topography Mission (SRTM) DEM (90 m). Contour map was generated based on ALOS $\mathrm{DEM}$ at an interval of 5 to $10 \mathrm{~m}$. Further, a relief map was also prepared with the help of DEM. It is also used as a key input to calculate sinuosity.

\subsubsection{Census Data}

Census data parameters viz. population density, house-hold density, total male, female population, agricultural labour, cultivator, and literacy rate were considered for mapping socio-economic vulnerable zones in the study region. All the parameters were taken from the Census of India 2011 survey database.

\subsection{Methods}

3.2.1. Flood Extent Mapping during 2001-2020 and Flood Hazard Estimation

In this study, MODIS-derived indices such as NDWI, mNDWI, SPWI, and EVI (Table 2) were applied to extract flood extents during 2001-2020 (July-September) by adopting threshold values. For instance, threshold values of more than $0,0.1$, and 0 were applied for NDWI, mNDWI, and SPWI, respectively for flood pixels extraction. The long-term flood extent maps were then utilized for producing flood frequency maps. Furthermore, the socio-economic dataset was coupled to generate vulnerability and finally flood risk. The comprehensive flowchart of the methodology has been given in Figure 3.

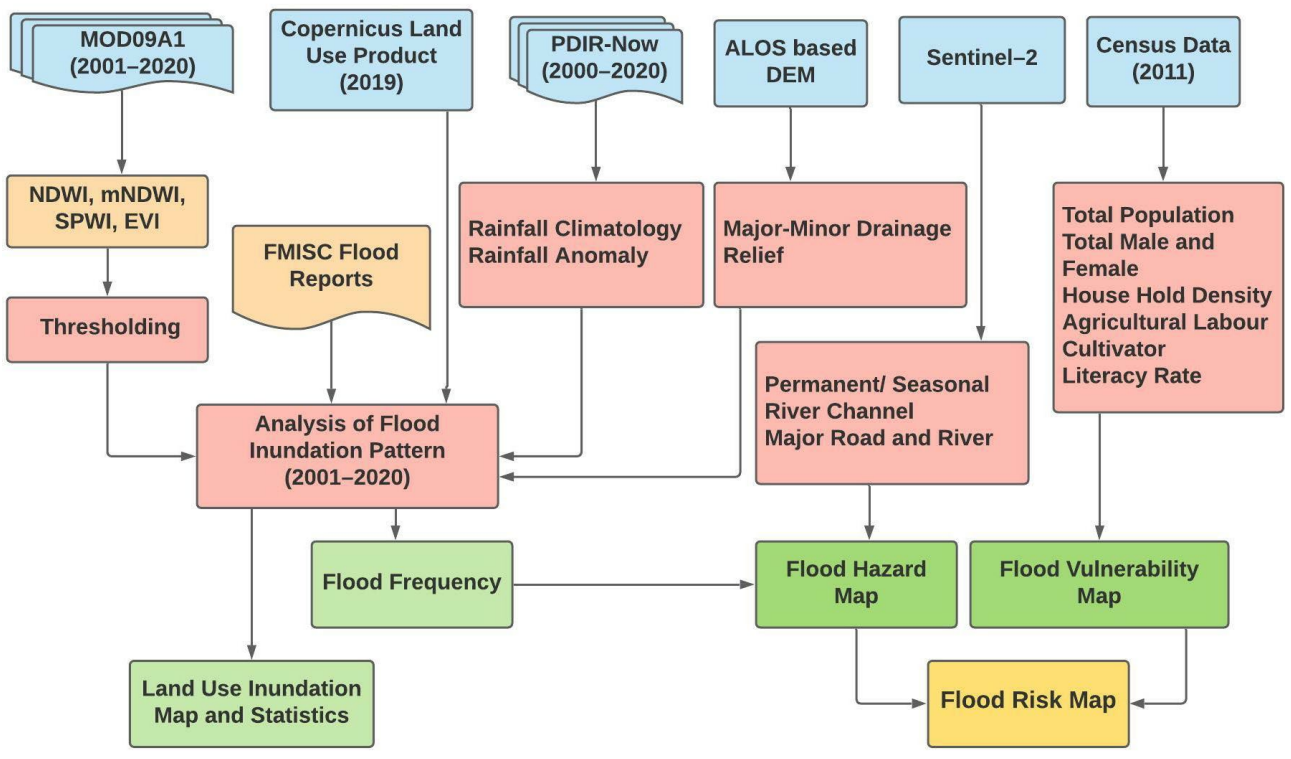

Figure 3. Methodology flow chart adopted in this study.

The NDWI highlights open waters from satellite images [17], whereas the mNDWI extracted shallow water bodies and separated built-up structures from water features [55]. SPWI is also capable of extracting water pixels accurately [22]. The EVI is represented as an optimized vegetation index to improve the vegetation signal with better sensitivity in high biomass areas. It is better than to as it reduced noises from atmospheric changes as well as soil background signals mainly in dense canopy zones [56,57]. The parameters adopted in 
the MODIS-EVI algorithm are $\mathrm{L}=1, \mathrm{C} 1=6, \mathrm{C} 2=7.5$, and $\mathrm{G}$ (gain factor) $=2.5$ and stated as follows:

- $\quad$ Non-flood pixel (EVI >0.3)

- $\quad$ Permanent water bodies $(E V I<0.05)$

- Water-related pixel (EVI < 0.1)

FMISC, Patna based flood inundation maps were also utilized to validate flood extent maps of this study during 2001-2020. The resultant 20 years flood maps at an annual basis were aggregated yearly in MATLAB R2020a to derive the frequency map. The aggregation process consists of three steps: (a) to read images using imread function, (b) to add images using imadd function, and (c) to display images using imshow function. At a time, two flood layers were added to create a flood frequency map.

Flood inundation extent of three months (during July, August, and September) were further aggregated and made annual flood inundation layer for each year during 20012020 based on (Equations (1)-(4)) and validated using the FMISC base flood maps. The yearly flood aggregated flood pixels were further used to derive flood frequency for each pixel. The composite flood extent maps for every 5 years (2001-2005, 2006-2010, 20112015, and 2015-2020) were prepared and the corresponding area statistics were generated. Furthermore, 20 years' composite flood extent map was also prepared to understand the long-term pattern as well as the impact of floods. However, flood frequency/occurrence for each flood pixel was estimated by considering all flood inundation layers from 2001 to 2020 on an annual basis. Furthermore, flood frequency is categorized into five different classes as shown in Table 3. Different flood hazard zones were considered based on the frequency of flood pixels e.g., Very High category is assigned to those pixels which have inundated $\geq 17$ times, High for 13-16 times, Moderate for 9-12 times, Low for 5-8 times, and Very Low to those pixels which inundated $\leq 4$ times.

Table 3. Flood hazard category and Flood frequency used in flood hazard map.

\begin{tabular}{cc}
\hline Flood Hazard Category & Flood Frequency \\
\hline Very High & $\geq 17$ times \\
\hline High & $13-16$ times \\
\hline Moderate & $09-12$ times \\
\hline Low & $05-08$ times \\
\hline Very Low & $\leq 04$ times \\
\hline
\end{tabular}

The intensity of flood hazard (FH) is calculated as follows:

$$
\mathrm{FH}=\left(\mathrm{YF}_{1}+\mathrm{YF}_{2}+\mathrm{YF}_{3}+\mathrm{YF}_{4}+\ldots \ldots \ldots \mathrm{YF}_{\mathrm{n}}\right)
$$

where $\mathrm{Y}$ indicates yearly flooding events and $\mathrm{F}_{\mathrm{n}}$ indicates flood frequency.

\subsubsection{Village Wise Socio-Economic Vulnerability (SEV) Mapping}

Flood vulnerability has been analyzed by many authors in the North Bihar region $[36,52]$. The most common concept of vulnerability is that it describes how a socio-economic system is susceptible to natural hazards. It is determined by including several factors the condition of human settlements, infrastructure, public policy and administration, organizational abilities, social inequalities, gender relations, economic patterns, etc. Census survey-based data were used in this study to get village-wise socio-economic vulnerability in terms of various several economic indicators, such as population density, sex ratio (male and female population), the population of cultivators, agricultural labourers, literacy rate, and house-hold density.

The present study has adopted the Socio-Economic Vulnerability (SEV) method developed by [58] to experiment with the spatial pattern to evaluate flood risk at village level to 
describe and understand the physical and social burdens of risk. Four consecutive steps were followed to calculate SEV are: (i) geo-spatial and non-geospatial data collection, processing, and analysis, (ii) integration of spatial and non-spatial data, (iii) weighted indexing of the socio-economic parameter, and (iv) integration of all parameters. The composite village-level SEV map was generated by integrating all seven socio-economic indicators. Then the SEV map was categorized into five classes, namely, very low, low, medium, high, and very high based on their attribute's class values from lowest to the highest (Table 4). Furthermore, five classes are assigned as 1 to 5 scale, where very low represents 1 and very high represents 5, and vice versa for literacy rate. The SEV is calculated as follows:

$$
\mathrm{SEV}=\mathrm{PD}+\mathrm{FM}+\mathrm{M}+\mathrm{AL}+\mathrm{CL}+\mathrm{CH}+\mathrm{LR} / \text { Number of Indicators }
$$

where,

$\mathrm{PD}=$ population density;

$\mathrm{HH}=$ number house-hold;

$\mathrm{FM}=$ female ratio;

$\mathrm{M}=$ percentage wise male ratio;

$\mathrm{AL}=$ percentage wise population of agricultural labourers;

$\mathrm{CL}=$ percentage wise population of cultivators;

$\mathrm{LR}=$ percentage population of literates.

Table 4. Several economic indicators divided in five different vulnerability categories based on their class values.

\begin{tabular}{|c|c|c|c|c|c|}
\hline Indicators & Very High & High & Moderate & Low & Very Low \\
\hline Population density per $\mathrm{km}^{2}\left(\mathrm{p} / \mathrm{km}^{2}\right)$ & $\geq 4000$ & $3000-4000$ & $2000-3000$ & $1000-2000$ & $\leq 1000$ \\
\hline House hold density (house $/ \mathrm{km}^{2}$ ) & $\geq 2000$ & $1500-2000$ & $1000-1500$ & $500-1000$ & $\leq 500$ \\
\hline Male Population (\%) & $36.1-45$ & $27.1-36$ & $18.1-27$ & $9.1-18$ & $\leq 9$ \\
\hline Female Population (\%) & $44.1-55$ & $33.1-44$ & $22.1-33$ & $11.1-22$ & $\leq 11$ \\
\hline Agriculture Labour (\%) & $\geq 56.1$ & $42.1-56$ & $28.1-42$ & $14.1-28$ & $\leq 14$ \\
\hline Cultivator (\%) & $\geq 44.1$ & $33.1-44$ & $22.1-33$ & $11.1-22$ & $\leq 11$ \\
\hline Literacy Rate (\%) & $\geq 24.1$ & $18.1-24$ & $12.1-18$ & $6.1-12$ & $\leq 6$ \\
\hline
\end{tabular}

\subsubsection{Flood Risk Mapping}

Flood Risk (R) was assessed by combining hazard (H) with vulnerability (SEV) as follows:

$$
\text { Risk }(\mathrm{R})=\mathrm{H} \times \mathrm{SEV}
$$

where $\mathrm{H}$ indicates hazard categories and SEV indicates vulnerability at village level. Various spatial analysis and geo-statistical tools are used for mapping and analyzing hazard and vulnerability. The village-level flood risk has been categorized in five classes viz; very low, low, medium, high, and very high.

\section{Results}

\subsection{Spatio-Temporal Precipitation Maps during 2000-2020}

The rainfall anomaly maps based on CHRS PDIR-Now data from July to September (i.e., mean) were shown in Figure 4. To assess the spatiotemporal rainfall variability across the Gandak (1), Burhi Gandak (2), Bagmati-Adhwara Group (3), Kamla-Balan (4), Kosi (5), and Mahananda river basin's catchment (6), we showed only for extreme rainfall years like $2004,2007,2008,2011,2017$, and 2020. The rainfall anomaly maps were presented to identify the districts as well as the basins (1-6), which received intense rainfall. Rainfall anomaly maps for the years 2004 (Figure 4a), 2007 (Figure 4b), 2008 (Figure 4c), 2011 (Figure 4d), 2017 (Figure 4e) and 2020 (Figure 4f) are showing heavy downpours during particular 
years with respect to the rest of the years during 2000-2020. These results showed that during the year 2004, the majority of areas of the study region has received rainfall up to $200 \mathrm{~mm}$. However, it is concentrated in the central part of the study region (i.e., Burhi Gandak, Bagmati-Adhwara Group, and Kamla-Balan basins) which further resulted in severe inundation in low catchment areas of North Bihar plain (Appendix A). The major district severely affected during the 2004 flooding event was Darbhanga, Madhepura, Katihar, and Khagaria (Figure A1). During the year 2007, it is shown that $6.4 \%$ of the geographical land of North Bihar districts got inundated (Figure A1g) due to severe rainfall occurred which were concentrated over the south-western part of the region (i.e., Gandak, Burhi Gandak, Bagmati-Adhwara Group and Kamla-Balan basins) with the rainfall of 100-200 mm, severely inundated Darbhanga, Katihar, Madhepura, and Purnea districts. During the year 2008, except upper catchment region especially in the western Nepal region, middle and lower catchment region has received rainfall up to $100 \mathrm{~mm}$. This unprecedented rainfall has resulted in breaching of Kosi river near Kushaha bridge at $12 \mathrm{~km}$ upstream from Kosi barrage which has been shown in Figure A1h. Rainfall anomaly map during the year 2011 has shown that except Tibetan plateau, the whole study region has received less than $50 \mathrm{~mm}$ of rainfall and therefore, flood extent areas are limited to a few districts, such as Muzzfarpur, Bhagalpur, Katihar, and Khagaria. As per the rainfall anomaly map of the year 2017, it can be stated that the Northern Bihar region has received the distributed rainfall between 50-150 $\mathrm{mm}$ and concentrated over the western and southern region (i.e., Gandak, Burhi Gandak, Bagmati-Adhwara Group, Kamla-Balan and Kosi basins). The affected districts were Darbhanga, Madhepura, Khagaria, Saharsa, Katihar, and Bhagalpur. During the year 2020, the study area has received excessive rainfall between 50-200 mm that concentrated over the south-western part of the basin (i.e., Gandak, Burhi Gandak, Bagmati-Adhwara Group, Kamla-Balan, Kosi and Mahananda basins). Consequently, it was found that $17.7 \%$ geographical land of the study region was inundated and severely affected districts are Muzzafarpur, Darbhanga, Saharsa, Khagaria, Madhepura, Bhagalpur, Katihar, and Purnea. Notably, we found that during the year 2020, the maximum rainfall was occurred followed by the years 2004 and 2007 over North Bihar, Nepal, and Tibetan Plateau which subsequently led to flood-like conditions over downstream areas. The precipitated water traveled through a gentle slope from the upper (Tibetan Plateau and Nepal) to the lower catchment of North Bihar. The rainfall was concentrated mostly over the northern and south-west part of the basin as displayed in Figure 4a-f.

Concisely, it can be stated that the higher rainfall events were observed during 2004, 2007, and 2020 and were majorly concentrated over low catchment areas of Gandak, Burhi Gandak, Bagmati-Adhwara Group, Kamla-Balan, Kosi, and Mahananda river basin's catchment. Moreover, the composite rainfall data also showed that rainfall was concentrated in central and lower catchment areas. The districts which were adversely affected due to torrential rainfall are Paschim and Purbi Champaran, Madhubani, Darbhanga, Supaul, Araria, Saharsa and Katihar. Apart from these, some of the districts, such as Madhepura, Samastipur, Muzzafarpur, Purnea, Sitamarhi, Sheohar, Begusarai, Bhagalpur, Kishanganj, and Vaishali also witnessed high-intensity rainfall and followed by flood inundation.

\subsection{Spatio-Temporal Annual Flood Extent Map during 2001-2020}

During the last two decades (2001-2020), North Bihar districts witnessed major flooding events during 2001, 2002, 2004, 2007, 2008, 2013, 2014, 2017, 2019 and 2020. The present study has shown the year-wise spatiotemporal flooding events during 2001-2020 in Figure A1 and their flood inundation area statistics in Figure A2. Five-year composite flood inundation maps (Figure 5) exhibited a common region of North Bihar which were recurrently affected in the last twenty years (2001-2020). During 2001-2005 and 2006-2011, flooding took place over the central part of the region along the Kosi and Adhwara group of rivers and severely affected, Muzaffarpur, Darbhanga, Samastipur, Saharsa, Khagaria, Katihar, and Purnea districts (Figure 5a,b). A total of $10490.5 \mathrm{~km}^{2}$ and $12594.8 \mathrm{~km}^{2}$ area was inundated along with Kosi and Bagmati-Adhwara group of rivers during 2001-2005 and 
2006-2010, respectively (Figure 5a,b). Notably, due to a breach near Kusaha in 2008, parts of Saharsa, Madhepura and Purnea districts were witnessed severe flood inundation, which can be seen in composite flood map during 2006-2010 (Figure 5b). During 2011-2015 and 2016-2020, an area of $8910.1 \mathrm{~km}^{2}$ (Figure 5c) and $24145.5 \mathrm{~km}^{2}$ (Figure 5d) were inundated, respectively and the latter one affected all most 19 districts in the North Bihar region.

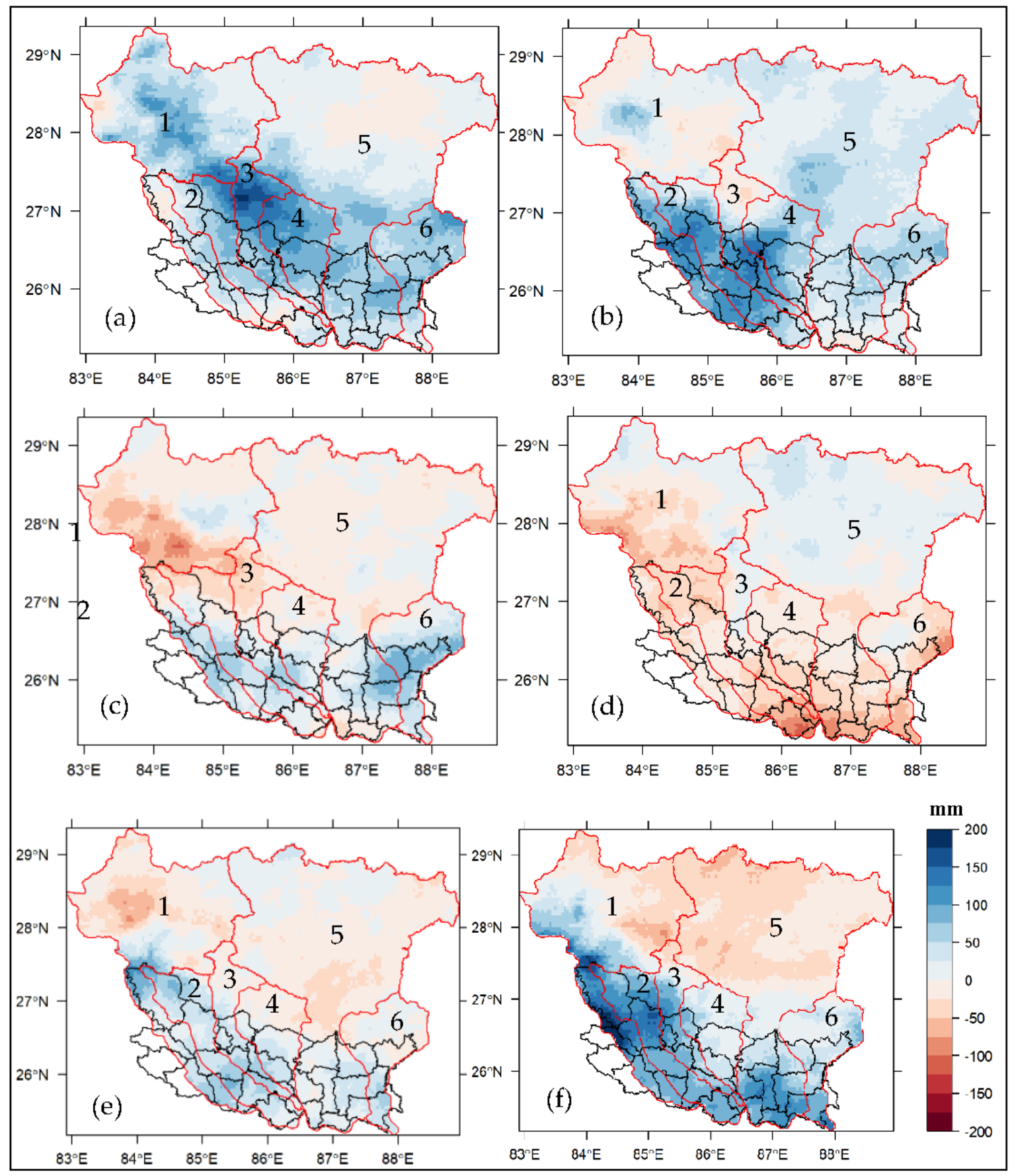

Figure 4. Rainfall anomaly (mm) maps (July to September) based on CHRS PDIR-Now during (a) 2004; (b) 2007; (c) 2008; (d) 2011; (e) 2017; and (f) 2020 . 


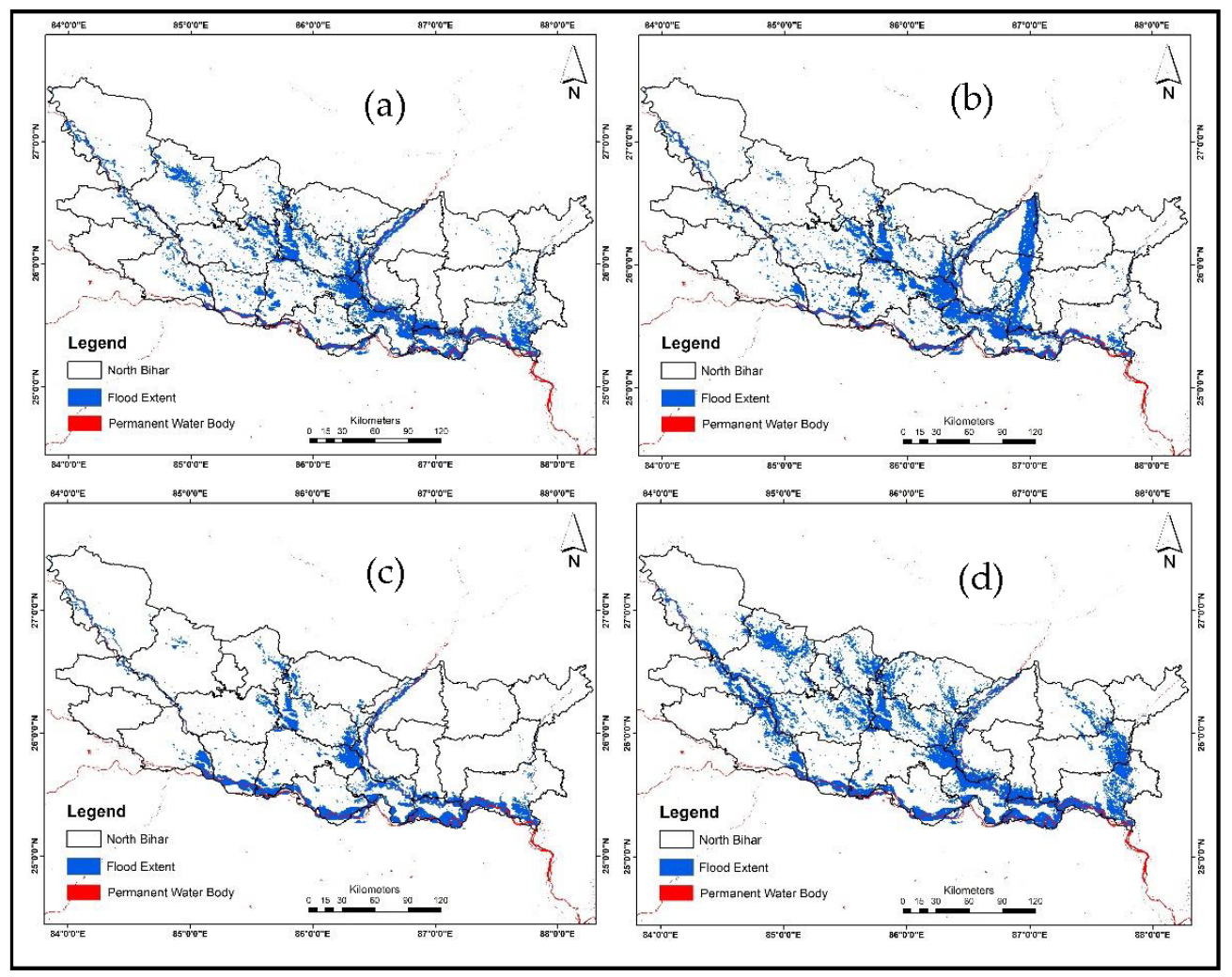

Figure 5. Five-year composite MOD09A1 based flood extent maps during (a) 2001-2005; (b) 20062010; (c) 2011-2015; (d) 2016-2020.

Flood inundated areas (i.e., hotspots) were majorly concentrated in the central part of North Bihar around Kosi and Bagmati-Adhwara group of rivers. Recurrent flood inundation due to the Ganges can be clearly seen over the last two decades, whereas, more prominent flooding was seen in the years 2013, 2016, 2019, and 2020 (Figure A1). The composite flood map over 2001-2020 has indicated that during the past two decades, onethird of Bihar's landmass was subjected to flooding accounting for $18640.24 \mathrm{~km}^{2}$ inundated areas $(\sim 34 \%)$. The study also exhibited that during extreme rainfall-induced flooding events in 2007,2019 , and 2020 , a total of $19 \%, 40 \%$, and $52 \%$ of land are got inundated with respect to the total flooded area (i.e., $18,640.24 \mathrm{~km}^{2}$ ) (Figures 5 and A1). Flood maps exhibit that among all the districts of North Bihar, Sheohar, Supaul, Darbhanga, Saharsa, Khagaria, Bhagalpur, and Katihar experienced very severe floods disaster and getting inundated recurrently due to its geographical settings located in the lower catchment areas. The cumulative map shows Kosi, Gandak, Mahananda, and Bagmati-Adhwara rivers are the major source of flood disaster in North Bihar while seasonal water channels also play a major role.

\subsection{Flood Hazard Assessment Based on Annual Flood Extent Map during 2001-2020}

The flood frequency map was also presented in Figure 6 which showed that the areas located along the river have the highest number of frequencies. The flood hazard category was done on the basis of flood occurrences during 2001-2020 (Table 5), a method which is similar to [7]. For instance, flood frequency of 17 to 20 times was classified under Very High (hazard zone, whereas 13 to 16 times were kept under high hazard zone. Similarly, the yellow color represents a moderate hazard zone with a frequency of 9 to 12 times, whereas the cyan color represented flood frequency of 5 to 8 times (i.e., Low hazard zone). The lowest frequency was $<4$ times and it was seen very far away from rivers and mostly seen due to a break in embankment (Figure 6). It is also evident from Figure A1 that the spatial distribution and extent of flooding varies from year to year. The areas that are 
common across the years were classified as the most vulnerable areas, such as the eastern, central and northern regions of North Bihar. Thus, produced flood maps are expected to be useful in identifying temporal changes in the simultaneous recession and expansion of flood cycles. It is evident based on the flood hazard map that North Bihar is mostly affected due to riverine floods where the Kosi river basin is a prime source for disaster occurrence followed by Bagmati-Adhwara, Kamla-Balan, Burhi Gandak, and Mahananda in the past 20 years.

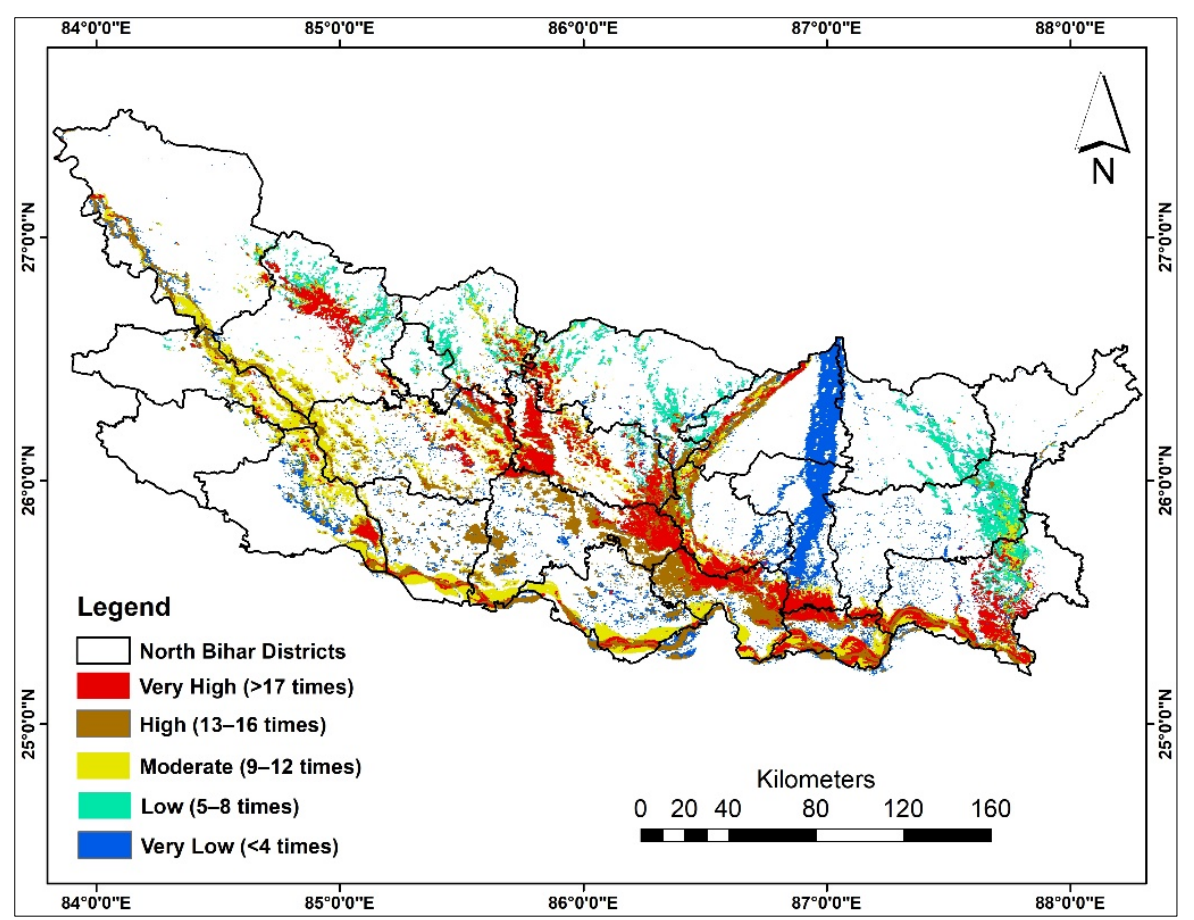

Figure 6. Annual flood occurrence map during 2001-2020 as derived from yearly flood maps.

Table 5. Flood hazard category and area statistics based on occurrences of floods during 2001-2020. The total geographical area is $54,223.02 \mathrm{~km}^{2}$.

\begin{tabular}{|c|c|c|c|c|}
\hline S1. No. & Hazard Category & $\begin{array}{l}\text { Flood Hazard Area } \\
\quad\left(\text { in } \mathbf{k m}^{2}\right)\end{array}$ & $\begin{array}{l}\text { \% Inundation } \\
\text { (with Respect to the } \\
\text { Geographical Area) }\end{array}$ & $\begin{array}{c}\text { \% Inundation } \\
\text { (with Respect to the } \\
\text { Total Inundation) }\end{array}$ \\
\hline 1. & Very High (>17) & 3687.13 & 6.8 & 19.8 \\
\hline 2. & High (13-16) & 4328.67 & 8 & 23.2 \\
\hline 3. & $\begin{array}{l}\text { Moderate } \\
(9-12)\end{array}$ & 3188.36 & 5.9 & 17.1 \\
\hline 4. & Low (5-8) & 4169.11 & 7.7 & 22.4 \\
\hline 5. & Very Low $(<4)$ & 3266.97 & 6.03 & 17.5 \\
\hline
\end{tabular}

Based on the spatiotemporal flood inundation events during 2001-2020, the magnitude of flood hazard was assessed and the impact across the North Bihar administrative boundary was mapped. Composite flood inundation extent during 2001-2020 shows $\sim 34 \%\left(18,640.24 \mathrm{~km}^{2}\right)$ of the land area got submerged, where the majority of the area is shared by high flood hazard zone $\left(4328.67 \mathrm{~km}^{2}\right)$ followed by Low $\left(4169.11 \mathrm{~km}^{2}\right)$, Very High $\left(3687.13 \mathrm{~km}^{2}\right)$, Very Low $\left(3266.97 \mathrm{~km}^{2}\right)$, and Moderate $\left(3188.36 \mathrm{~km}^{2}\right)$ (Table 5). 


\subsection{Flood Impact Assessment on LULC}

The predominant LULC classes are agriculture and vegetation (i.e., forest, shrublands) which account for $27,648 \mathrm{~km}^{2}(51 \%)$ and $10,773 \mathrm{~km}^{2}(19.9 \%)$, respectively (Figure 7). The area under the settlement, others, and water body classes were $5590 \mathrm{~km}^{2}(10.3 \%)$ and $6569 \mathrm{~km}^{2}(12.11 \%)$, and $3643 \mathrm{~km}^{2}(6.71 \%)$, respectively. The flood inundation impact on different LULC classes was evaluated using flood frequency map as derived from 20012020 and the corresponding statistics were shown in Table 6. The results exhibited that floods were prominent in agricultural (8.6\%) and settlement $(2.2 \%)$ areas as both accounted for $\sim 10.8 \%$ areas were affected by floods, under very high category (Table 6). Similarly, agricultural land followed by vegetation and other land use classes showed $9.9 \%, 5.5 \%$, and $7.4 \%$ of inundation under the high flood hazard category. Under the moderate hazard category, prominently agricultural land showed about $7.7 \%$ inundation of total agricultural area. Similarly, in the low hazard category agricultural land was heavily affected followed by others and vegetation land-use class with $10.3 \%, 7 \%$, and $5 \%$ of inundation, respectively. Agricultural Land was inundated prominently in the very low hazard category with $8.4 \%$ of total agricultural area.

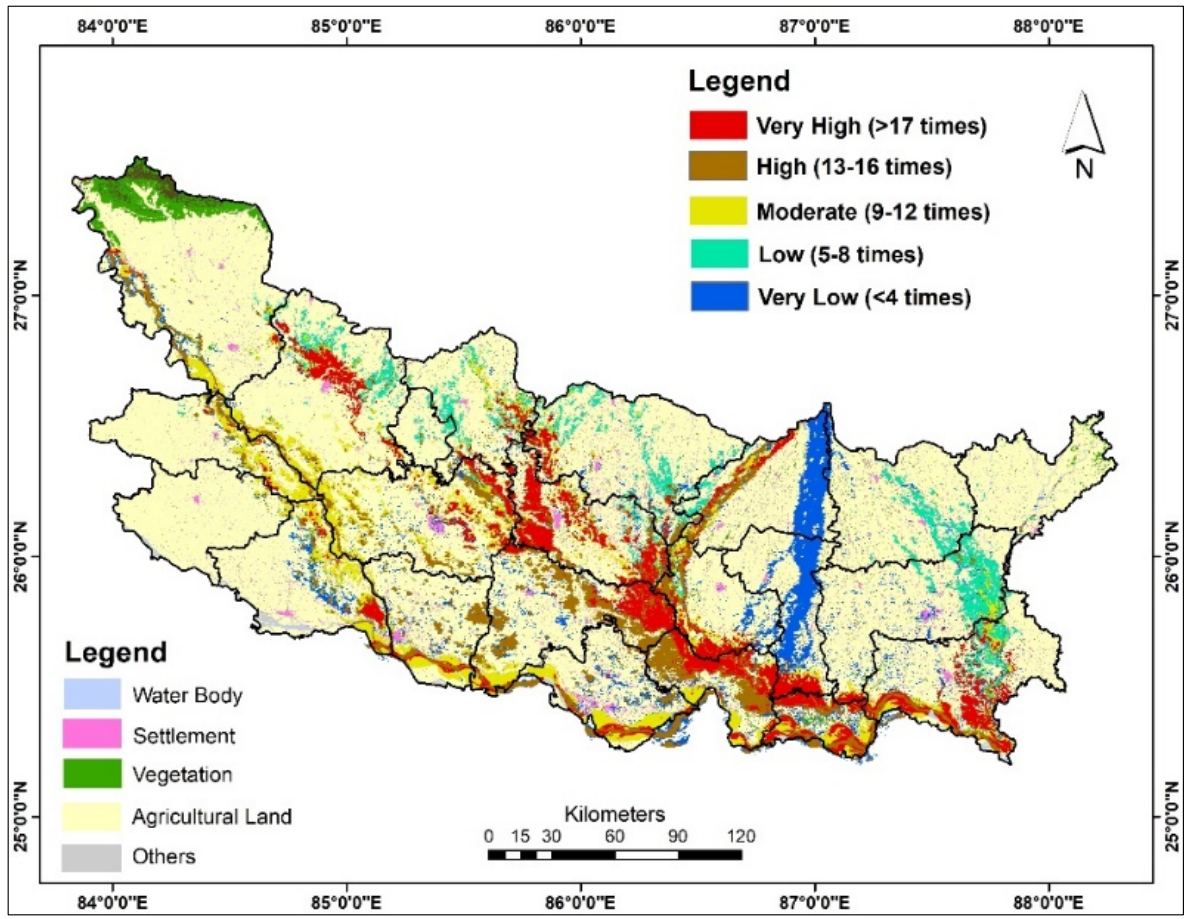

Figure 7. Flood frequency map as derived from 2001-2020 overlaid on Copernicus based land use land cover (LULC) map.

Table 6. Area statistics (in $\mathrm{km}^{2}$ ) of category wised flood-affected LULC classes. The $\%$ area affected (shown in bracket) is with respect to a total area of corresponding LULC.

\begin{tabular}{cccccc}
\hline $\begin{array}{c}\text { Hazard } \\
\text { Category }\end{array}$ & Water Body & Settlement & Vegetation & Agriculture & Others \\
\hline Vey High & $322.8(8.9 \%)$ & $122.4(2.2 \%)$ & $402.1(3.7 \%)$ & $2366.9(8.6 \%)$ & $473.1(7.2 \%)$ \\
\hline High & $371.6(10.2 \%)$ & $137(2.5 \%)$ & $587.3(5.5 \%)$ & $2746.4(9.9 \%)$ & $486.4(7.4 \%)$ \\
\hline Moderate & $298.6(8.2 \%)$ & $98.1(1.8 \%)$ & $428.7(4 \%)$ & $2126.4(7.7 \%)$ & $236.6(3.6 \%)$ \\
\hline Low & $227.3(6.2 \%)$ & $108.5(1.9 \%)$ & $536.3(5 \%)$ & $2837.5(10.3 \%)$ & $459.5(7 \%)$ \\
\hline Very Low & $267.3(7.3 \%)$ & $95.4(1.7 \%)$ & $356.1(3.3 \%)$ & $2331.4(8.4 \%)$ & $216.9(3.3 \%)$ \\
\hline
\end{tabular}




\subsection{Socio-Economic Vulnerability (SEV) and Flood Risk Map}

Village level Socio-economic vulnerability (SEV) was assessed based on socio-economic factors taken from Census data collected during 2011. It was observed that districts present in central, eastern, and northern regions (i.e., East-Champaran, Sheohar, Sitamarhi, Darbhanga, Muzaffarpur, Katihar, Khagaria, Madhepura, Purnea, and Supaul) were under very-high vulnerability zone, whilst the north and central region (i.e., Sheohar, Madhubani, Darbhanga, Samastipur, Supaul Begusarai, and Saharsa) falls under high vulnerability zone (Figure 8a). The central part of the northern plains area alone accounted for $19.11 \%$ $\left(12,376.17 \mathrm{~km}^{2}\right)$ of the inundated area under high to very high-vulnerability zone. Apart from this, the eastern part (i.e., Araria, Madhepura, Purnea, Katihar, Bhagalpur, and Khagaria) showed under the moderate vulnerable zone. Some districts such as West Champaran and Kishanganj are under the low and very low vulnerable zone, respectively. The analysis exhibited that a total of $10,976.36 \mathrm{~km}^{2}$ and $8139.76 \mathrm{~km}^{2}(20.24 \%$ and $15.01 \%$ of total geographical area) were estimated under very high and high SEV, respectively. The moderate SEV category accounts for $14,671.2 \mathrm{~km}^{2}$ of area $(27.06 \%)$. Similarly, the low and very low categories have accounted for $9466.6 \mathrm{~km}^{2}(17.46 \%)$ and $10,969.1 \mathrm{~km}^{2}$ of land area (20.23\%), respectively. The study also exhibited that among 23,632 villages in the North Bihar region, 4719 and 3571 villages are seen under very high and high vulnerability zones (Table 7).
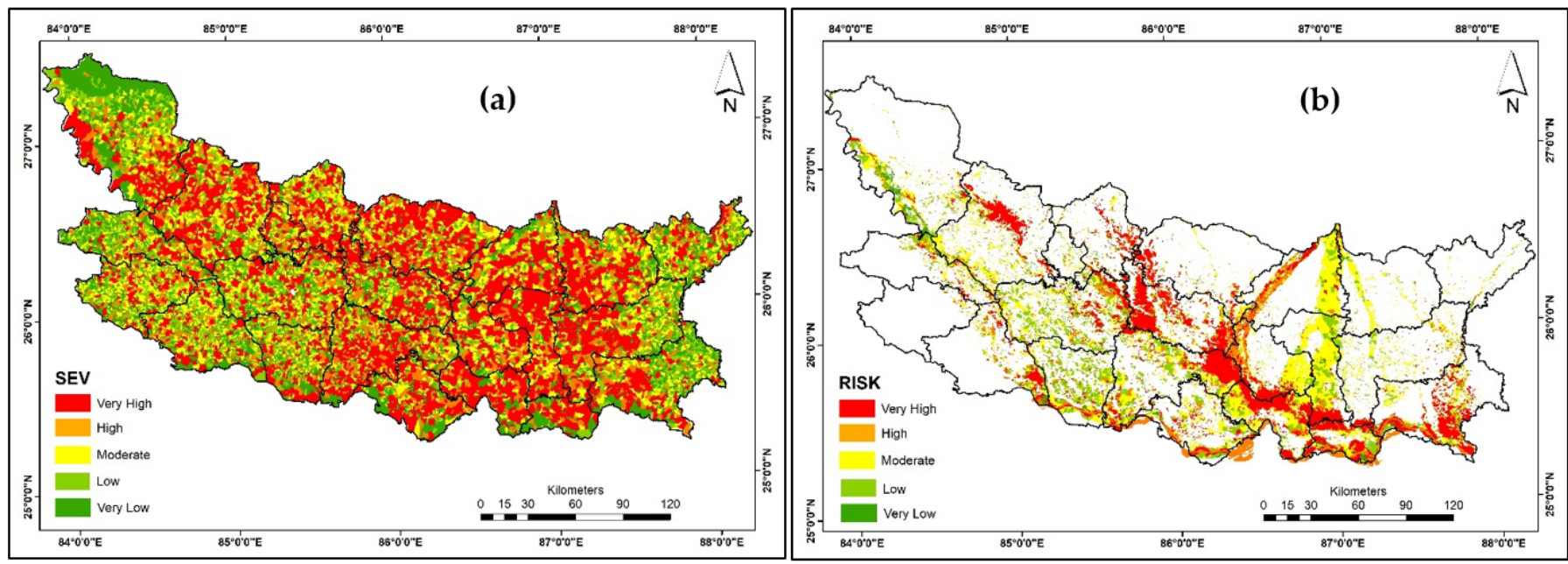

Figure 8. Village (a) level Socio-Economic Vulnerability (SEV) and (b) Flood Risk map.

Table 7. The number of villages affected as per the SEV and flood risk. The total number of villages in the North Bihar region is 23,632.

\begin{tabular}{ccc}
\hline Category & SEV & Flood Risk \\
\hline Vey High & 4719 & 2770 \\
\hline High & 3571 & 3535 \\
\hline Moderate & 6391 & 5094 \\
\hline Low & 4218 & 1297 \\
\hline Very Low & 4733 & 896 \\
\hline
\end{tabular}

Village level Flood risk areas were estimated based on varied flood hazard and vulnerability categories (Figure 8). It was found that villages situated along the river i.e., Kosi, Gandak, Burhi-Gandak, Kamla-Balan, were seen under high to very high flood risk zone. Villages located in the Mahananda basin are prominently under moderate risk zone. However, villages under low and very low-risk categories can be seen in the central-western region in Figure 8b. Darbhanga is the most flood-affected district during the last twenty 
years with $587.7 \mathrm{~km}^{2}$ ( $\sim 26 \%$ of total Darbhanga geographical area) of inundation. Around 116 and 135 villages are under very high and high flood risk zone, whereas 87 villages came under moderate flood risk zone. Around 56 and 61 villages are considered in low-risk and very low-risk categories, respectively.

The study also exhibited that a total of $3973.64 \mathrm{~km}^{2}$ (7.33\% of total geographical area) and $4582.14 \mathrm{~km}^{2}(8.45 \%)$ areas have been classified under very high and high flood risk zone, respectively. Whereas, $6833.86 \mathrm{~km}^{2}$ area $(12.6 \%)$ was shown under moderate flood risk zone. About $2187.67 \mathrm{~km}^{2}(4.03 \%)$ and $1063.25 \mathrm{~km}^{2}(1.96 \%)$ areas were classified under low and very low flood risk categories. The number of affected villages in each category of flood risk has been shown in Table 7 . The total number of flood-affected villages under different risk categories was 13,592.

\section{Discussion}

India's $40 \%$ of the land area is vulnerable to flood, whilst North Bihar itself shares $17 \%$ of the area [50]. The major rivers such as Kosi, Gandak, Burhi-Gandak, BagmatiAdhwara group, Mahananda always brings riverine flood during the monsoon season almost every year. Hence, understanding flood inundation character based on long-term flooding pattern data becomes essential information which further could be used to develop long-term flood management strategies in the North Bihar regions. The present study has utilized MOD09A1 satellite data to generate composite rainfall at every 5 years during 2001-2020. The study also reveals that during 2016-2020, on average half of the total North Bihar ( $45 \%$ area) was inundated with a total area of $24,145.5 \mathrm{~km}^{2}$ (Figure $5 \mathrm{~d}$ ) which affected all most all 23 districts of the North Bihar region followed by extreme rainfall events (Figure 4e,f). Flood impact assessment on varied land use classes was shown that $\sim 45 \%$ of the agricultural land area was inundated followed by vegetation and settlement with $\sim 22 \%$ and $\sim 10 \%$ inundation, respectively. As per the long-term aggregated flood extent map, it was found that $18,640 \mathrm{~km}^{2}(\sim 34 \%)$ area was inundated. However, it fluctuates year to year with a minimum flood area $\sim 969 \mathrm{~km}^{2}(\sim 2 \%)$ in the year 2013 and the maximum flooded area of $9607.45 \mathrm{~km}^{2}(\sim 18 \%)$ in the year 2020 . The fluctuation of area inundation is mainly attributed to rainfall received in upstream areas which can be seen in 2020 flood events. There was as such no study that was done for a longer period (2001-2020) for flood area mapping. However, some studies have been conducted by taking a single year that has been employed with MODIS NRT or SAR-based satellite data. The MODIS-based NRT based results indicated that $\sim 9230 \mathrm{~km}^{2}(\sim 17 \%)$ area was inundated due to the 2019 flood event over North Bihar [49]. Moreover, the spatial pattern of flood in this study was quite consistent with previous studies [49]. Flood extent map reveals that villages along Kosi, Gandak, and Burhi-Gandak rivers are more prone to flooding due to the availability of several major and minor river channels which activate during monsoons and contribute heavily to major streams to inundate low lying areas. Flood risk depends on a combination of the physical nature of flood severity and its interaction with a population or vulnerability. To study the risk of flood hazards, it is essential to study the severity, and spatial extent of these hazards as well as the socioeconomic ability of the region to anticipate and cope with the hazards.

In the present study, a geohazard map has been derived by integrating long-term flood information, SEV map to deduce the flood risk pattern at the village level. There is no such study carried out to assess flood risk at village level in the North Bihar region. However, some studies evaluated flood risk at district and block levels based on various indicators namely, major/minor river channels, road networks, hydro-geomorphology, sinuosity, demographics, flood report, and economic index [15,38,59]. A significant rainfall contribution from the upstream Himalayan region makes this region highly vulnerable to flood. The present study revealed that villages of the districts such as Bhagalpur, Darbhanga, Khagaria, and Samastipur are considered to be at very high risk owing to their geographical setting as it is located in lower catchment areas with a gentle slope and several seasonal/permanent river channels. It was also studied that pre and post- 
monsoon waterlogging zones are prominently present in these districts owing to lower relief zones [60]. Flood not only causes population at risk but also agricultural loss and severe economic damages [15]. The study also suggested that braided and meandering river channels play a key role in flooding patterns $[53,61]$. Similarly, the flood risk map presented in Figure 8b, exhibited that very high flood risk areas can be seen prominently in the central and northern part of North Bihar region whereas some of the areas from central, eastern and western parts of the region can be seen under moderate to high flood risk zone. These areas of higher risk to flood are mainly attributed to regional hydro-geomorphology such as the presence of lower relief zones, waterlogging zones, flood plains, paleochannels, oxbow lakes, etc. The study also exhibited that a higher degree of sinuosity is also a key reason behind the occurrence of severe flooding phenomena. Moreover, siltation deposition and lack of maintenance of sediments from dams and barrages are also reported to be major factors for increasing flood events and associated damages [30]. Studies also projected that climate change-induced extreme rainfall intensity would be higher for the future and therefore, higher risk can be anticipated [3,4,31]. However, Kosi fan areas, part of Mahananda basin, and western region are showing under in moderate flood risk which can be attributed to inactive flood plains as well as shallow to deep alluvial plains [60]. Similarly, villages showing in Gandak and Burhi Gandak river basin are under low and very low flood risk category and primarily due to embankment structures, lower drainage density and lower sinuosity as well. However, low-quality structures or break-in embankments usually show higher flood damages across North Bihar. Additionally, deforestation at river banks and increasing urban compactness are some factors that could increase flood risks at river banks.

Flood risk evaluation becomes even more important when climate change induced extreme weather events are intensifying the flood events. According to the data provided by IPCC 2021 [8], there have been more than 999 natural disasters in the last 20 twenty years, of which 951 were related to weather resulting havoc situations in lower catchment regions. This has caused a lot of damage to the economy. Considering all these factors, it can be stated that flood hazard, vulnerability and risk estimation are very important to reduce the loss of life and property by incorporating high resolution satellite data and 1-D, 2-D, and 3-D hydrological and hydro-dynamic models $[4,7,62]$. Several studies have coupled high resolution satellite data with numerical models to evaluate flood risk [5,40]. Studies have indicated that without including the socio-economic data with the meteorological, geomorphological, geological, and historical flood data, the flood risk assessment will be considered as unfinished work $[43,58,61]$. The present study has employed MCDM approaches for flood risk mapping, which has used very limited input parameters. The socio-economic data were utilized from the Census 2011 survey report which is a decadeold dataset. As the latest Census dataset are not available, the derived SEI from Census 2011 dataset may be underestimated the vulnerability. Accordingly, the risk map of the present study may be underestimated flood-related vulnerability and risk. The availability of updated socio-economic data could lead to evaluate flood risk zone more efficiently. Nevertheless, the derived flood risk maps would be helpful to develop a flood preparedness plan during the mitigation process and risk assessment. Additional limitations of this study are unavailability of historical flood data and several hydro-climatic data. This study involved coarse spatial but high temporal resolution optical remote sensing satellite data (MOD09A1) to evaluate flood hazard over North Bihar. To overcome the shortcoming of optical remote sensing data owing to cloud cover, SAR-based satellite data can be used to map flood extent by integrating with several hydrodynamic and deep learning-based models.

It is worth mentioning that there is a scope to use high-resolution DEM data along with additional and updated socio-economic parameters and flood conditioning factors (i.e., geomorphology, Topographic wetness index, soil texture, curvature, and geology, among others) for flood risk zone mapping. More in-situ data can also be used to strengthen the models as well as the analysis. The AHP method coupled with GIS has been widely used for Flood susceptibility mapping (FSM), but other approaches, namely frequency ratio, fuzzy 
logic, machine learning (e.g., support vector machines), artificial neural network (ANN), and hydrological models (e.g., SWAT, HEC-RAS, MIKE) can be applied for identifying the flood risk zones accurately.

\section{Conclusions}

The present study has demonstrated the utility of multi-temporal satellite images of MOD09A1 in understanding flood inundation dynamics (i.e., flood progression and regression) during 2001-2020. Furthermore, the potential of satellite-derived flood frequency map and socio-economic data in assessing flood hazard, vulnerability, and risk. The key findings suggested that flood events of 2007, 2017, 2019, and 2020 were the major disasters due to heavy downpours which inundated $6.4 \%, 5.8 \%, 13.8 \%$, and $17.7 \%$ of total North Bihar's geographical area, respectively. Flood frequency exhibited that nearly $7 \%$ and $8 \%$ of the area of North Bihar is categorized under very high and high hazard category. As per the composite flood inundation over 2001-2020, 34\% of the total geographical area was affected and among the LULC category, agricultural land and settlement were adversely affected. Census of India (2011) based composite socio-economic vulnerability map showed that the central part of North Bihar region and preferably region along the rivers are having greater vulnerability which is further proved based on flood risk map. The flood risk map also showed that the central North Bihar region along the river was categorized in high to very high flood risk zone, affecting 6305 villages.

Based on the capability of space-based data and its cost-effectiveness in flood disaster management, satellite data are useful for monitoring flood patterns as well as flood occurrences. The MCDM approaches can help disaster managers in the state to take mitigation measures for prioritizing susceptible zones and flood mitigation measures. The digital spatial database on the spatial distribution of flood hazards prepared for the North Bihar state will serve as important baseline information for taking up flood mitigation activities and also assist in taking flood insurance measures in flood-affected regions. The inundation map and associated impact and risk information will help decision-makers to provide an operational service for flood management.

Author Contributions: G.T., A.C.P. and B.R.P.: Conceptualization, Investigation, Methodology, Software, Analysis, Visualization, writing —original draft, review and editing. All authors have read and agreed to the published version of the manuscript.

Funding: This research received no external funding.

Institutional Review Board Statement: Not applicable.

Informed Consent Statement: Not applicable.

Data Availability Statement: Publicly available datasets were analyzed in this study. This data can be found from the Source mentioned in Table 1.

Acknowledgments: Our sincere thanks to LP DAAC, Alaska Satellite Facility (ASF), Copernicus ESA, CHRS Data Portal, and Census of India for providing MOD09A1, Land Use Land Cover product, Rainfall data, and Socio-economic data, respectively used in this study. We also thank FMISC, Patna for providing flood maps during 2001-2020.

Conflicts of Interest: The authors declare no conflict of interest. 


\section{Appendix A}

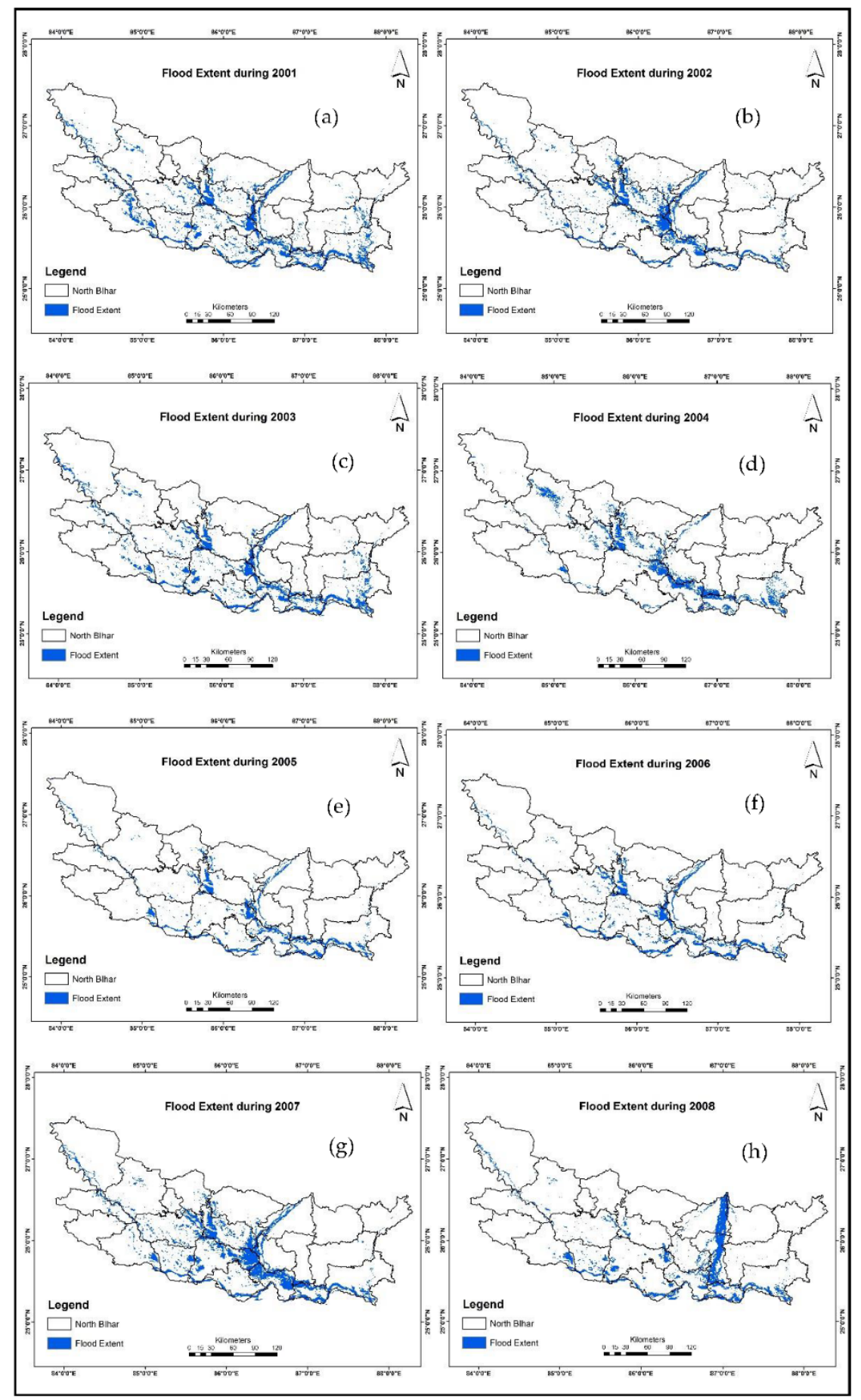

Figure A1. Cont. 


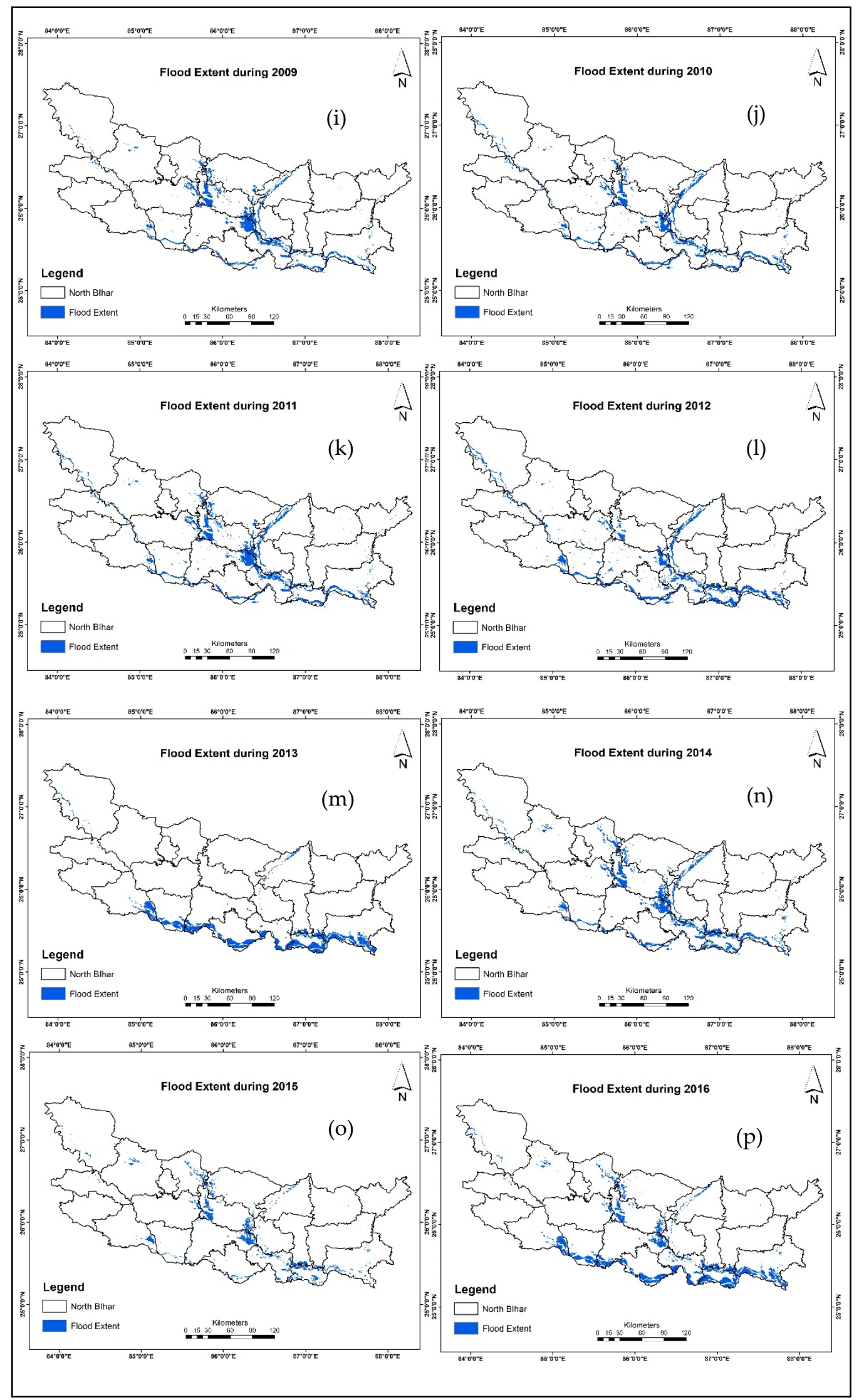

Figure A1. Cont. 


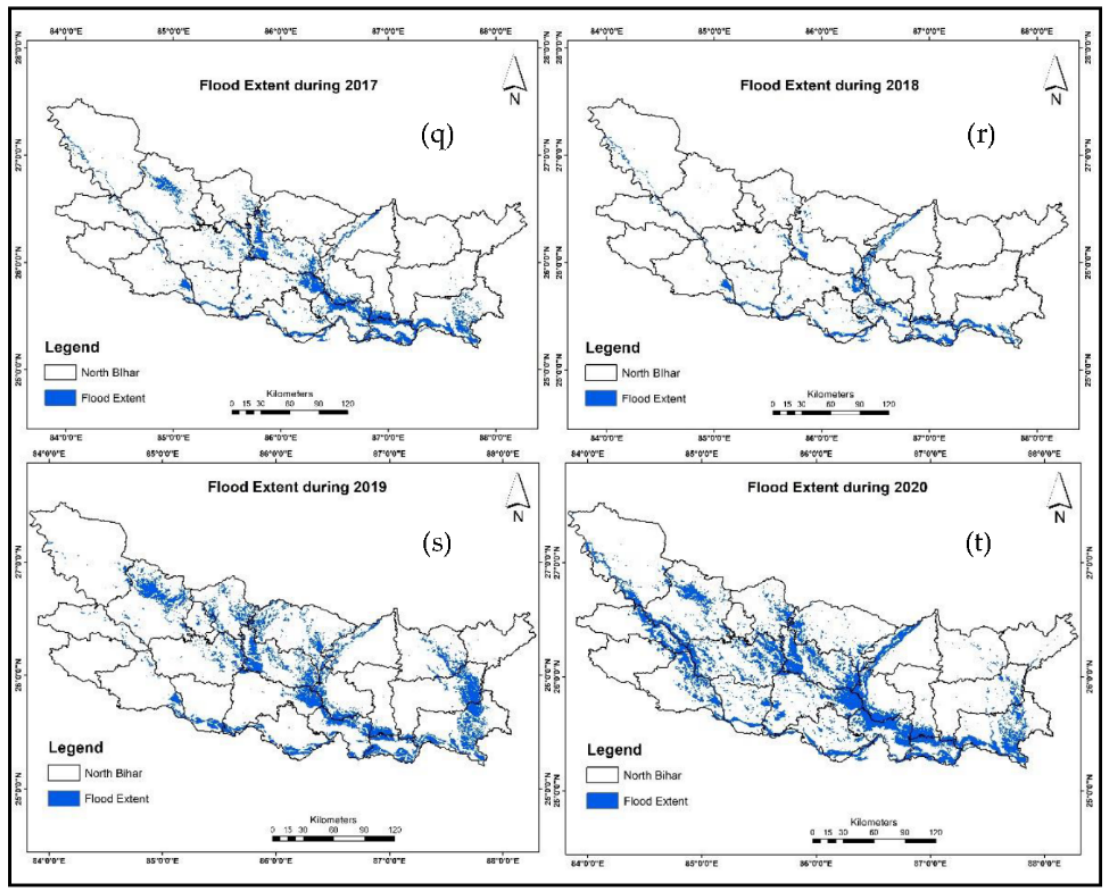

Figure A1. Annual flood extent map during 2001-2020 based on multiple indices from MOD09A1 reflectance data. (a) Flood Extent during 2001, (b) Flood Extent during 2002, (c) Flood Extent during 2003, (d) Flood Extent during 2004, (e) Flood Extent during 2005, (f) Flood Extent during 2006, (g) Flood Extent during 2007, (h) Flood Extent during 2008, (i) Flood Extent during 2009, (j) Flood Extent during 2010, (k) Flood Extent during 2011, (1) Flood Extent during 2012, (m) Flood Extent during 2013, (n) Flood Extent during 2014, (o) Flood Extent during 2015, (p) Flood Extent during 2016, (q) Flood Extent during 2017, (r) Flood Extent during 2018, (s) Flood Extent during 2019, (t) Flood Extent during 2020.

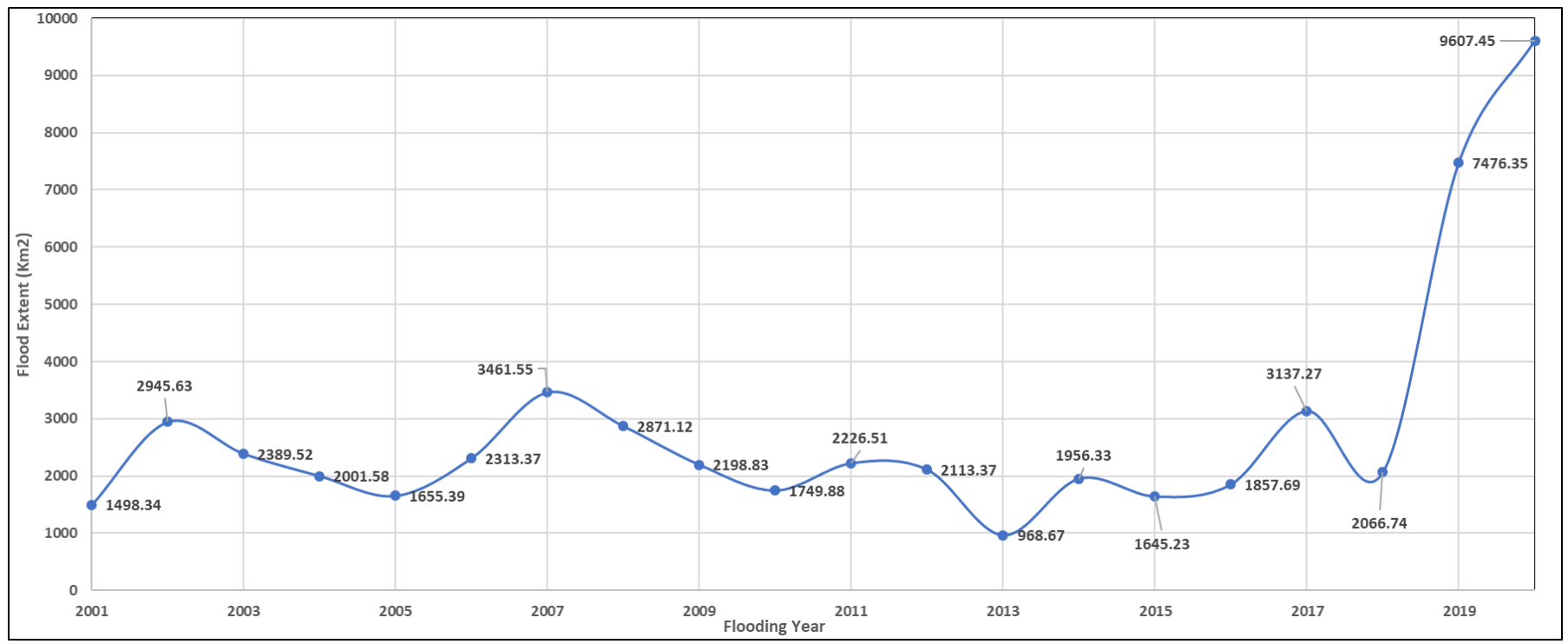

Figure A2. Flooding year with respect to the flood extent (in $\mathrm{km}^{2}$ ) during 2001-2020. 


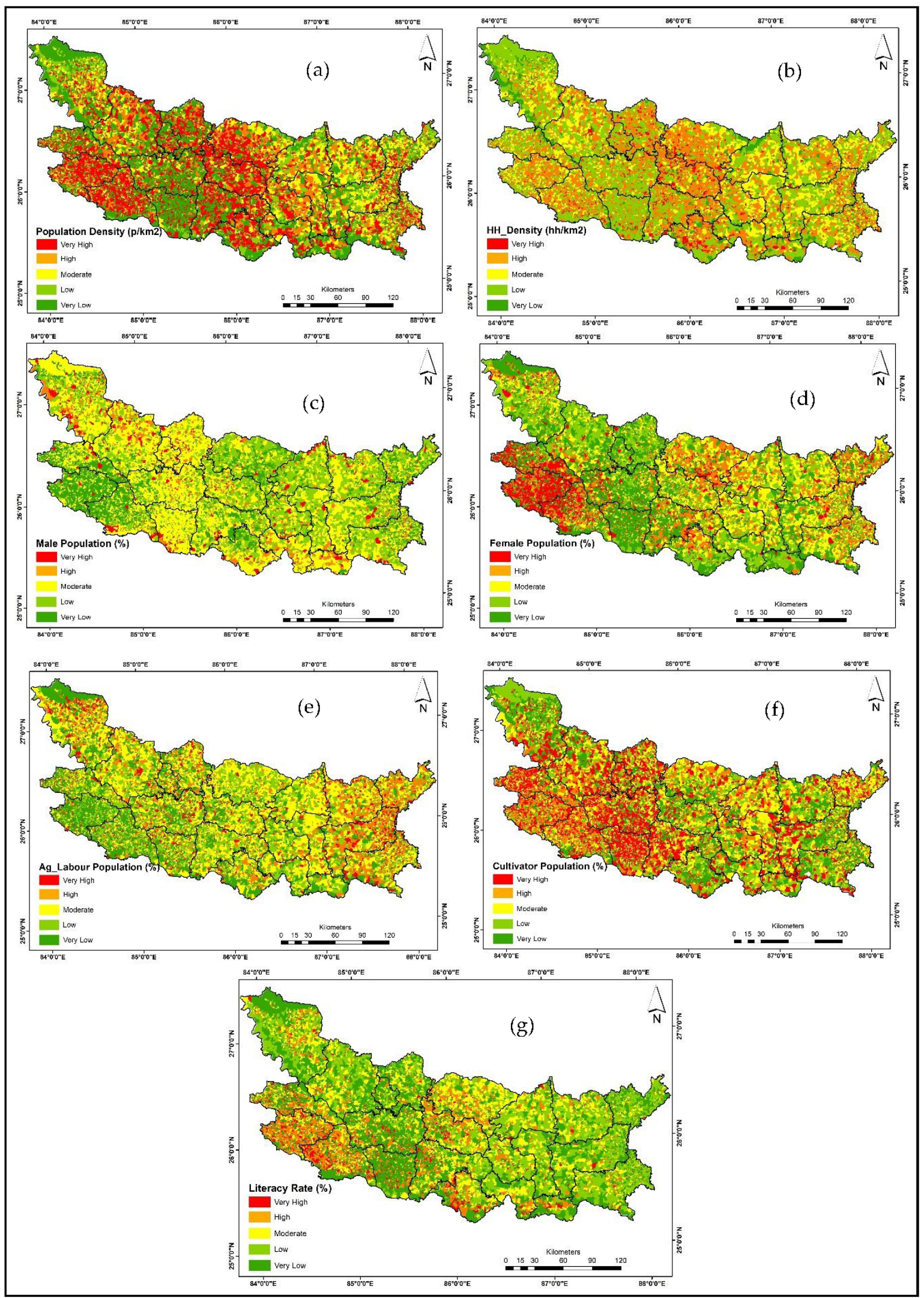

Figure A3. Socio-economic indicators map showing (a) population density $\left(\mathrm{p} / \mathrm{km}^{2}\right)$, (b) house-hold density $\left(\mathrm{hh} / \mathrm{km}^{2}\right)$, (c) male population (\%), (d) female population (\%), (e) agricultural labour (\%), (f) cultivator population $(\%)$, and (g) literacy rate $(\%)$. 


\section{References}

1. Samela, C.; Manfreda, S.; Troy, T.J. Dataset of 100-Year Flood Susceptibility Maps for the Continental U.S. Derived with a Geomorphic Method. Data Brief 2017, 12, 203-207. [CrossRef]

2. Tripathi, G.; Parida, B.R.; Pandey, A.C. Spatio-Temporal Rainfall Variability and Flood Prognosis Analysis Using Satellite Data over North Bihar during the August 2017 Flood Event. Hydrology 2019, 6, 38. [CrossRef]

3. Blöschl, G.; Hall, J.; Viglione, A.; Perdigão, R.A.P.; Parajka, J.; Merz, B.; Lun, D.; Arheimer, B.; Aronica, G.T.; Bilibashi, A.; et al. Changing Climate Both Increases and Decreases European River Floods. Nature 2019, 573, 108-111. [CrossRef]

4. Loukas, A.; Garrote, L.; Vasiliades, L. Hydrological and Hydro-Meteorological Extremes and Related Risk and Uncertainty. Water 2021, 13, 377. [CrossRef]

5. Haltas, I.; Demir, I.; Yildirim, E.; Oztas, F. A Comprehensive Flood Event Specification and Inventory: 1930-2020 Turkey Case Study. Int. J. Disaster Risk Reduct. 2021, 56, 102086. [CrossRef]

6. Kulp, S.A.; Strauss, B.H. New Elevation Data Triple Estimates of Global Vulnerability to Sea-Level Rise and Coastal Flooding. Nat. Commun. 2019, 10, 4844. [CrossRef]

7. Shivaprasad Sharma, S.V.; Sharma, S.; Roy, P.S. Extraction of Detailed Level Flood Hazard Zones Using Multi-Temporal Historical Satellite Data-Sets-A Case Study of Kopili River Basin, Assam, India. Geomat. Nat. Hazards Risk 2017, 8, 792-802. [CrossRef]

8. IPCC, 2021: Climate Change 2021: The Physical Science Basis. Contribution of Working Group I to the Sixth Assessment Report of the Intergovernmental Panel on Climate Change; Cambridge University Press: Cambridge, UK, 2021.

9. Boyaj, A.; Ashok, K.; Ghosh, S.; Devanand, A.; Dandu, G. The Chennai Extreme Rainfall Event in 2015: The Bay of Bengal Connection. Clim. Dyn. 2018, 50, 2867-2879. [CrossRef]

10. Chandrababu, D. Record Rainfall Wreaks Havoc in Chennai. Hindustan Times New Delhi, 8 November 2021. Available online: https:/ / www.hindustantimes.com/india-news/record-rainfall-wreaks-havoc-in-chennai-101636310510384.html (accessed on 25 November 2021).

11. Bisht, D.S.; Chatterjee, C.; Kalakoti, S.; Upadhyay, P.; Sahoo, M.; Panda, A. Modeling Urban Floods and Drainage Using SWMM and MIKE URBAN: A Case Study. Nat. Hazards 2016, 84, 749-776. [CrossRef]

12. Alahacoon, N.; Matheswaran, K.; Pani, P.; Amarnath, G. A Decadal Historical Satellite Data and Rainfall Trend Analysis (2001-2016) for Flood Hazard Mapping in Sri Lanka. Remote Sens. 2018, 10, 448. [CrossRef]

13. .Belabid, N.; Zhao, F.; Brocca, L.; Huang, Y.; Tan, Y. Near-Real-Time Flood Forecasting Based on Satellite Precipitation Products. Remote Sens. 2019, 11, 252. [CrossRef]

14. Rai, P.K.; Singh, P.; Mishra, V.N.; Kumar, J.; Sahoo, S. Monitoring North Bihar Flood of 2020 Using Geospatial Technologies. In It Is Correct Recent Technologies for Disaster Management and Risk Reduction; Earth and Environmental Sciences Library; Springer International Publishing: New York, NY, USA, 2021; pp. 135-155. ISBN 978-3-030-76115-8.

15. Matheswaran, K.; Alahacoon, N.; Pandey, R.; Amarnath, G. Flood Risk Assessment in South Asia to Prioritize Flood Index Insurance Applications in Bihar, India. Geomat. Nat. Hazards Risk 2019, 10, 26-48. [CrossRef]

16. Parida, B.R.; Tripathi, G.; Pandey, A.C.; Kumar, A. Estimating Floodwater Depth Using SAR-Derived Flood Inundation Maps and Geomorphic Model in Kosi River Basin (India). Geocarto Int. 2021, 1-26. [CrossRef]

17. McFeeters, S.K. The Use of the Normalized Difference Water Index (NDWI) in the Delineation of Open Water Features. Int. J. Remote Sens. 1996, 17, 1425-1432. [CrossRef]

18. Guerschman, J.P.; Warren, G.; Byrne, G.; Lymburner, L.; Mueller, N.; Van Dijk, A.I.J.M. MODIS-Based Standing Water Detection for Flood and Large Reservoir Mapping: Algorithm Development and Applications for the Australian Continent. CSIRO 2011. [CrossRef]

19. Singh, K.V.; Setia, R.; Sahoo, S.; Prasad, A.; Pateriya, B. Evaluation of NDWI and MNDWI for Assessment of Waterlogging by Integrating Digital Elevation Model and Groundwater Level. Geocarto Int. 2015, 30, 650-661. [CrossRef]

20. Patel, N.R.; Mukund, A.; Parida, B.R. Satellite-Derived Vegetation Temperature Condition Index to Infer Root Zone Soil Moisture in Semi-Arid Province of Rajasthan, India. Geocarto Int. 2022, 37, 179-195. [CrossRef]

21. Sakamoto, T.; Van Nguyen, N.; Kotera, A.; Ohno, H.; Ishitsuka, N.; Yokozawa, M. Detecting Temporal Changes in the Extent of Annual Flooding within the Cambodia and the Vietnamese Mekong Delta from MODIS Time-Series Imagery. Remote Sens. Environ. 2007, 109, 295-313. [CrossRef]

22. Zhou, S.L.; Zhang, W.C. Flood Monitoring and Damage Assessment in Thailand Using Multi-Temporal HJ-1A/1B and MODIS Images. IOP Conf. Ser. Earth Environ. Sci. 2017, 57, 012016. [CrossRef]

23. Sajjad, A.; Lu, J.; Chen, X.; Saleem, N. Rapid Riverine Flood Mapping with Different Water Indexes Using Flood Instances Landsat-8 Images. In Proceedings of the 5th International Electronic Conference on Water Sciences, Online, 16-30 November 2020; MDPI: Basel, Switzerland, 2020; p. 8049. Available online: http://sciforum.net/conference/ECWS-5/paper/8049 (accessed on 13 November 2020).

24. Jain, S.K.; Singh, R.D.; Jain, M.K.; Lohani, A.K. Delineation of Flood-Prone Areas Using Remote Sensing Techniques. Water Resour. Manag. 2005, 19, 333-347. [CrossRef]

25. Kumar, R.; Singh, R.; Gautam, H.; Pandey, M.K. Flood Hazard Assessment of August 20, 2016 Floods in Satna District, Madhya Pradesh, India. Remote Sens. Appl. Soc. Environ. 2018, 11, 104-118. [CrossRef]

26. Shakya, A.; Biswas, M.; Pal, M. CNN-Based Fusion and Classification of SAR and Optical Data. Int. J. Remote Sens. 2020, 41, 8839-8861. [CrossRef] 
27. Haque, M.M.; Seidou, O.; Mohammadian, A.; Gado Djibo, A. Development of a Time-Varying MODIS/2D Hydrodynamic Model Relationship between Water Levels and Flooded Areas in the Inner Niger Delta, Mali, West Africa. J. Hydrol. Reg. Stud. 2020, 30, 100703. [CrossRef]

28. Mekanik, F.; Imteaz, M.A.; Gato-Trinidad, S.; Elmahdi, A. Multiple Regression and Artificial Neural Network for Long-Term Rainfall Forecasting Using Large Scale Climate Modes. J. Hydrol. 2013, 503, 11-21. [CrossRef]

29. Xu, Z.X.; Li, J.Y. Short-Term Inflow Forecasting Using an Artificial Neural Network Model. Hydrol. Process. 2002, 16, 2423-2439. [CrossRef]

30. Abbot, J.; Marohasy, J. Input Selection and Optimisation for Monthly Rainfall Forecasting in Queensland, Australia, Using Artificial Neural Networks. Atmos. Res. 2014, 138, 166-178. [CrossRef]

31. Gizaw, M.S.; Gan, T.Y. Regional Flood Frequency Analysis Using Support Vector Regression under Historical and Future Climate. J. Hydrol. 2016, 538, 387-398. [CrossRef]

32. Mosavi, A.; Ozturk, P.; Chau, K. Flood Prediction Using Machine Learning Models: Literature Review. Water 2018, 10, 1536. [CrossRef]

33. Shakya, A.; Biswas, M.; Pal, M. Parametric Study of Convolutional Neural Network Based Remote Sensing Image Classification. Int. J. Remote Sens. 2021, 42, 2663-2685. [CrossRef]

34. Sinha, R.; Bapalu, G.V.; Singh, L.K.; Rath, B. Flood Risk Analysis in the Kosi River Basin, North Bihar Using Multi-Parametric Approach of Analytical Hierarchy Process (AHP). J. Indian Soc. Remote Sens. 2008, 36, 335-349. [CrossRef]

35. Mishra, K.; Sinha, R. Flood Risk Assessment in the Kosi Megafan Using Multi-Criteria Decision Analysis: A Hydro-Geomorphic Approach. Geomorphology 2020, 350, 106861. [CrossRef]

36. Baky, M.A.A.; Islam, M.; Paul, S. Flood Hazard, Vulnerability and Risk Assessment for Different Land Use Classes Using a Flow Model. Earth Syst. Environ. 2020, 4, 225-244. [CrossRef]

37. Islam, M.M.; Sado, K. Development of Flood Hazard Maps of Bangladesh Using NOAA-AVHRR Images with GIS. Hydrol. Sci. J. 2000, 45, 337-355. [CrossRef]

38. Jha, R.K.; Gundimeda, H. An Integrated Assessment of Vulnerability to Floods Using Composite Index-A District Level Analysis for Bihar, India. Int. J. Disaster Risk Reduct. 2019, 35, 101074. [CrossRef]

39. Basheer Ahammed, K.K.; Pandey, A.C. Coastal Social Vulnerability and Risk Analysis for Cyclone Hazard Along the Andhra Pradesh, East Coast of India. KN J. Cartogr. Geogr. Inf. 2019, 69, 285-303. [CrossRef]

40. Phongsapan, K.; Chishtie, F.; Poortinga, A.; Bhandari, B.; Meechaiya, C.; Kunlamai, T.; Aung, K.S.; Saah, D.; Anderson, E.; Markert, K.; et al. Operational Flood Risk Index Mapping for Disaster Risk Reduction Using Earth Observations and Cloud Computing Technologies: A Case Study on Myanmar. Front. Environ. Sci. 2019, 7, 191. [CrossRef]

41. Deepak, S.; Rajan, G.; Jairaj, P.G. Geospatial Approach for Assessment of Vulnerability to Flood in Local Self Governments. Geoenviron. Disasters 2020, 7, 35. [CrossRef]

42. Hazarika, N.; Barman, D.; Das, A.K.; Sarma, A.K.; Borah, S.B. Assessing and Mapping Flood Hazard, Vulnerability and Risk in the Upper Brahmaputra River Valley Using Stakeholders' Knowledge and Multicriteria Evaluation (MCE): Assessing and Mapping Flood Hazard. J. Flood Risk Manag. 2018, 11, S700-S716. [CrossRef]

43. Shadmehri Toosi, A.; Calbimonte, G.H.; Nouri, H.; Alaghmand, S. River Basin-Scale Flood Hazard Assessment Using a Modified Multi-Criteria Decision Analysis Approach: A Case Study. J. Hydrol. 2019, 574, 660-671. [CrossRef]

44. Burn, D.H.; Goel, N.K. The Formation of Groups for Regional Flood Frequency Analysis. Hydrol. Sci. J. 2000, 45, 97-112. [CrossRef]

45. Roder, G.; Hudson, P.; Tarolli, P. Flood Risk Perceptions and the Willingness to Pay for Flood Insurance in the Veneto Region of Italy. Int. J. Disaster Risk Reduct. 2019, 37, 101172. [CrossRef]

46. Hudson, P.; Botzen, W.J.W.; Aerts, J.C.J.H. Flood Insurance Arrangements in the European Union for Future Flood Risk under Climate and Socioeconomic Change. Glob. Environ. Chang. 2019, 58, 101966. [CrossRef]

47. Masood, M.; Takeuchi, K. Assessment of Flood Hazard, Vulnerability and Risk of Mid-Eastern Dhaka Using DEM and 1D Hydrodynamic Model. Nat. Hazards 2012, 61, 757-770. [CrossRef]

48. Hoque, M.A.-A.; Ahmed, N.; Pradhan, B.; Roy, S. Assessment of Coastal Vulnerability to Multi-Hazardous Events Using Geospatial Techniques along the Eastern Coast of Bangladesh. Ocean. Coast. Manag. 2019, 181, 104898. [CrossRef]

49. Bhatt, C.M.; Gupta, A.; Roy, A.; Dalal, P.; Chauhan, P. Geospatial Analysis of September, 2019 Floods in the Lower Gangetic Plains of Bihar Using Multi-Temporal Satellites and River Gauge Data. Geomat. Nat. Hazards Risk 2021, 12, 84-102. [CrossRef]

50. Manjusree, P.; Bhatt, C.M.; Begum, A.; Rao, G.S.; Bhanumurthy, V. A Decadal Historical Satellite Data Analysis for Flood Hazard Evaluation: A Case Study of Bihar (North India). Singap. J. Trop. Geogr. 2015, 36, 308-323. [CrossRef]

51. Tripathi, G.; Pandey, A.C.; Parida, B.R.; Shakya, A. Comparative Flood Inundation Mapping Utilizing Multi-Temporal Optical and SAR Satellite Data Over North Bihar Region: A Case Study of 2019 Flooding Event Over North Bihar. In Spatial Information Science for Natural Resource Management; Advances in Environmental Engineering and Green Technologies; IGI Publisher: Hershey, PA, USA, 2020; p. 20, ISBN 978-1-79985-027-4.

52. Pandey, A.C.; Singh, S.K.; Nathawat, M.S. Waterlogging and Flood Hazards Vulnerability and Risk Assessment in Indo Gangetic Plain. Nat. Hazards 2010, 55, 273-289. [CrossRef]

53. Gaurav, K.; Métivier, F.; Devauchelle, O.; Sinha, R.; Chauvet, H.; Houssais, M.; Bouquerel, H. Morphology of the Kosi Megafan Channels. Earth Surf. Dyn. 2015, 3, 321-331. [CrossRef] 
54. Tripathi, G.; Pandey, A.C.; Parida, B.R.; Kumar, A. Flood Inundation Mapping and Impact Assessment Using Multi-Temporal Optical and SAR Satellite Data: A Case Study of 2017 Flood in Darbhanga District, Bihar, India. Water Resour. Manag. 2020, 34, 1871-1892. [CrossRef]

55. Xu, H. Modification of Normalised Difference Water Index (NDWI) to Enhance Open Water Features in Remotely Sensed Imagery. Int. J. Remote Sens. 2006, 27, 3025-3033. [CrossRef]

56. Jiang, Z.; Huete, A.; Didan, K.; Miura, T. Development of a Two-Band Enhanced Vegetation Index without a Blue Band. Remote Sens. Environ. 2008, 112, 3833-3845. [CrossRef]

57. Parida, B.R.; Kumari, A. Mapping and Modeling Mangrove Biophysical and Biochemical Parameters Using Sentinel-2A Satellite Data in Bhitarkanika National Park, Odisha. Model. Earth Syst. Environ. 2021, 7, 2463-2474. [CrossRef]

58. Cutter, S.L. The Vulnerability of Science and the Science of Vulnerability. Ann. Assoc. Am. Geogr. 2003, 93, 1-12. [CrossRef]

59. Sarkar, D.; Saha, S.; Mondal, P. GIS-Based Frequency Ratio and Shannon's Entropy Techniques for Flood Vulnerability Assessment in Patna District, Central Bihar, India. Int. J. Environ. Sci. Technol. 2021, 1-22. [CrossRef]

60. Singh, S.K.; Pandey, A.C. Geomorphology and the Controls of Geohydrology on Waterlogging in Gangetic Plains, North Bihar, India. Environ. Earth Sci. 2014, 71, 1561-1579. [CrossRef]

61. Gaurav, K.; Tandon, S.K.; Devauchelle, O.; Sinha, R.; Métivier, F. A Single Width-Discharge Regime Relationship for Individual Threads of Braided and Meandering Rivers from the Himalayan Foreland. Geomorphology 2017, 295, 126-133. [CrossRef]

62. Amarnath, G.; Matheswaran, K.; Pandey, P.; Alahacoon, N.; Yoshimoto, S. Flood mapping tools for disaster preparedness and emergency response using satellite data and hydrodynamic models: A case study of Bagmathi Basin, India. Proc. Natl. Acad. Sci. India Sect. A Phys. Sci. 2017, 4, 941-950. [CrossRef] 